\title{
The Emerging Landscape of p53 Isoforms in Physiology, Cancer and Degenerative Diseases
}

\author{
Thineskrishna Anbarasan (1) and Jean-Christophe Bourdon * \\ School of Medicine, University of Dundee, Dundee DD1 9SY, UK; t.anbarasan@dundee.ac.uk \\ * Correspondence: j.bourdon@dundee.ac.uk
}

Received: 31 October 2019; Accepted: 9 December 2019; Published: 11 December 2019

check for updates

\begin{abstract}
: p53, first described four decades ago, is now established as a master regulator of cellular stress response, the "guardian of the genome". p53 contributes to biological robustness by behaving in a cellular-context dependent manner, influenced by several factors (e.g., cell type, active signalling pathways, the type, extent and intensity of cellular damage, cell cycle stage, nutrient availability, immune function). The p53 isoforms regulate gene transcription and protein expression in response to the stimuli so that the cell response is precisely tuned to the cell signals and cell context. Twelve isoforms of p53 have been described in humans. In this review, we explore the interactions between p53 isoforms and other proteins contributing to their established cellular functions, which can be both tumour-suppressive and oncogenic in nature. Evidence of p53 isoform in human cancers is largely based on RT-qPCR expression studies, usually investigating a particular type of isoform. Beyond p53 isoform functions in cancer, it is implicated in neurodegeneration, embryological development, progeroid phenotype, inflammatory pathology, infections and tissue regeneration, which are described in this review.
\end{abstract}

Keywords: p53; isoforms; cancer; p53 response

\section{Introduction}

p53, first described four decades ago, is established as the "guardian of the genome" or master regulator of cellular damage response [1]. In response to a mutagenic or stress stimulus (e.g., nutrient deprivation) or changes in cell signalling and tissue homeostasis, p53 is activated, initiating different adaptive protein expression programs to maintain/restore tissue integrity and biological functions by triggering and coordinating different cell fate decisions in the diverse cell types composing the damaged organs. p53 induces and coordinates cell repair, cell survival, senescence, migration of immune, endothelial and progenitor cells, stem-cell renewal, differentiation and cell death depending on the cell type and function, the active signalling pathways, the type of damage, the cell cycle stage, nutrient availability, the immune response and the presence of pathogens [2-7].

p53 is at the hub of the cell signal pathways, being modified post-translationally and simultaneously by a plethora of diverse modifying enzymes (acetyl-transferase, deacetylase, methyltransferase, demethylase, ubiquitin-ligase, deubiquitinase, kinases, phosphatases, Poly-ADP ribose polymerase (PARP)) that are regulated by very different cell sensors and receptors $[2,3,8]$. In other words, p53, via regulating gene expression, integrates simultaneously many different cell signals and contribute to their translation into a cellular response precisely adapted to the type and context of the cell.

Adopting a dualistic perspective, the seemingly paradoxical effects of p53 become apparent, for instance, being able to transactivate both proapoptotic (BAX, PUMA and NOXA) and anti-apoptotic $(p 21,14-3-3 \sigma)$ genes. Aptly described as "antagonistic bifunctionality", this highlights the nature of p53 to mediate varied, at instances paradoxical cellular responses, influenced by the dynamic environment the cell is in $[9,10]$. Further supporting its dualistic nature, the cellular biochemical functions of p53, 
in addition to expected tumour suppressive effects, can have an oncogenic influence. The extent of the p53-mediated cellular functions still remains undefined. Furthermore, unlike conventional tumour suppressors, which are not expressed in human cancers due to non-sense mutation (stop) or gene deletion, p53 often undergoes missense mutations that do not entirely abolish all p53 biochemical activities [11,12]. It may explain why TP53 mutations despite being the most frequently observed in human cancers, do not strictly correlate at the individual level to the patient's clinical outcome [13-15].

The two distinct promoters of TP53 gene (P1: upstream of exon1, and P2: within intron4), the alternative splicing and the alternative translation initiation sites of the different TP53 mRNA lead to the co-expression of p53 proteins with different protein-interacting domains and activities (p53 isoforms) [16,17]. This review focuses on the current understanding of p53 isoforms and explores their established implications in both physiology and disease.

\section{Generation of Human p53 Isoforms}

The human TP53 gene, as a transcription factor, comprises 13 exons (11 exons and 2 alternate spliced exons) located on chromosome 17p13.1 [18]. First observation of p53 splice variants was reported in the mid-1980s, but it was only 25 years after that TP53 splice variants were discovered in various species, and their biological and clinical relevance established $[19,20]$. Alternative splicing of human TP53 intron 9 was subsequently described. Till date, twelve protein isoforms of p53 (p53 $\alpha$, p53 3 , p53 $\gamma, \Delta 40 \mathrm{p} 53 \alpha, \Delta 40 \mathrm{p} 53 \beta, \Delta 40 \mathrm{p} 53 \gamma, \Delta 133 \mathrm{p} 53 \alpha, \Delta 133 \mathrm{p} 53 \beta, \Delta 133 \mathrm{p} 53 \gamma, \Delta 160 \mathrm{p} 53 \alpha, \Delta 160 \mathrm{p} 53 \beta, \Delta 160 \mathrm{p} 53 \gamma)$ encoded by 9 TP53 mRNA transcripts, expressed differentially in tissues, have been described and characterized in humans [16,21-24].

p53 isoforms are generated as a result of a combination of the use of alternative promoters ( $\mathrm{P} 1$ and P2), alternative splicing and alternative initiation of translation [22]. Canonical TP53 transcription initiates at promoter P1. In humans, alternative splicing can occur to produce variants retaining intron 2 and intron9. Alternative splicing at intron 9 can produce mRNA variants with either inclusion of exon $9 \beta$ or $9 \gamma$, giving rise to $\beta$ and $\gamma$ isoforms, respectively. Stop codons are present in exon $9 \beta$ and $9 \gamma$; hence exons 10 and 11 remain untranslated for the $\beta$ and $\gamma$ TP53 mRNA splice variants. The p53 mRNA transcribed from P1 promoter with spliced-out intron- 2 can be translated from the first AUG (present in exon 2) generating $\mathrm{p} 53 \alpha, \mathrm{p} 53 \beta$ and $\mathrm{p} 53 \gamma$ proteins and from AUG40 due to an internal ribosome entry site in the $5^{\prime}$ UTR from exon1-exon2 leading to the co-expression of $\Delta 40 \mathrm{p} 53 \alpha, \Delta 40 \mathrm{p} 53 \beta$, $\triangle 40 \mathrm{p} 53 \gamma$ isoforms $[25,26]$. From the TP53 mRNA transcripts retaining the intron 2 (which contains stop codons), translation can only be initiated at AUG 40 producing thus only the $\Delta 40 \mathrm{p} 53$ isoforms $(\Delta 40 \mathrm{p} 53 \alpha, \Delta 40 \mathrm{p} 53 \beta, \Delta 40 \mathrm{p} 53 \gamma$ isoforms) $[16,22]$.

Transcription of TP53 mRNA can initiate from internal promoter P2 located at intron 4 . Translation of these transcripts from initiating codons 133 and 160 can generate $\Delta 133$ p53 and $\Delta 160$ p53 isoforms, respectively. Considering alternative splicing at intron 9, these transcripts give rise to isoforms ( $\Delta 133$ p53 $\alpha, \Delta 133$ p53 $\beta, \Delta 133$ p53 $\gamma, \Delta 160$ p53 $\alpha, \Delta 160$ p53 $\beta$ and $\Delta 160 p 53 \gamma$ isoforms) [22].

\section{Conservation and Structure of p53 and Its Isoforms}

The TP53 gene has a dual gene structure that is conserved in several species such as zebrafish, drosophila, mouse and humans [22,27]. In drosophila, the Dmp53 gene is the biological functional equivalent of the TP53 gene. Two protein isoforms, DTAp53 and D $\triangle N p 53$, homologous to $\Delta 40 \mathrm{p} 53$ isoforms have been identified to be encoded by Dmp53. DTAp53 possesses the transactivation domain (TAD) defined by the highly conserved first 40 amino acids also detected in human p53 $\alpha$ [16,28]. The zebrafish Zp53 gene encodes Zp53 $\alpha$, Zp53 $\beta, Z \Delta N p 53 \alpha$ and $Z \Delta 113 p 5 \alpha$ isoforms. Other isoforms, associated with $Z p 53$ polymorphisms, have been detected in some zebrafish strains [28-30]. In mouse, the TP53 homologue, MsTP53 has till date been described to encode four isoforms, Mp53 $\alpha$, Mp53AS, $\mathrm{M} \triangle 41 \mathrm{p} 53 \alpha$ and $\mathrm{Mp} 53 \Psi$ [31,32].

p53 $\alpha$ (canonical p53) is a DNA-sequence specific regulator of transcription orchestrating the expression of more than 3000 genes [33]. In its active state, p53 $\alpha$ exists as a tetramer or stacking of 
tetramer on DNA [34]. p53 $\alpha$ contains seven functional domains, as illustrated in Figure 1. The intrinsic disorder region (IDR), present in the $\mathrm{N}$-terminal region, is an increasingly observed feature in proteins with influential roles within a signalling cascade [35]. IDRs allow a protein to form highly specific interactions with other functional proteins, albeit with low affinity $[35,36]$. The TADs comprised within the IDR is characterized by fleeting interactions with a wide range of proteins essential to the transcriptional activator function of p53 proteins. TADs can interact with components of the transcription machinery, chromatin modifiers, DNA metabolism proteins (e.g., PC4, HMGB1) and p53-modifying enzymes (e.g., MDM2, p300) [37]. From a functional perspective, TAD1 is integral for apoptosis and DNA damage-induced G1 arrest and both TAD 1/2 for mediating specific signalling pathways in the tumour suppressive response of p53 [38].

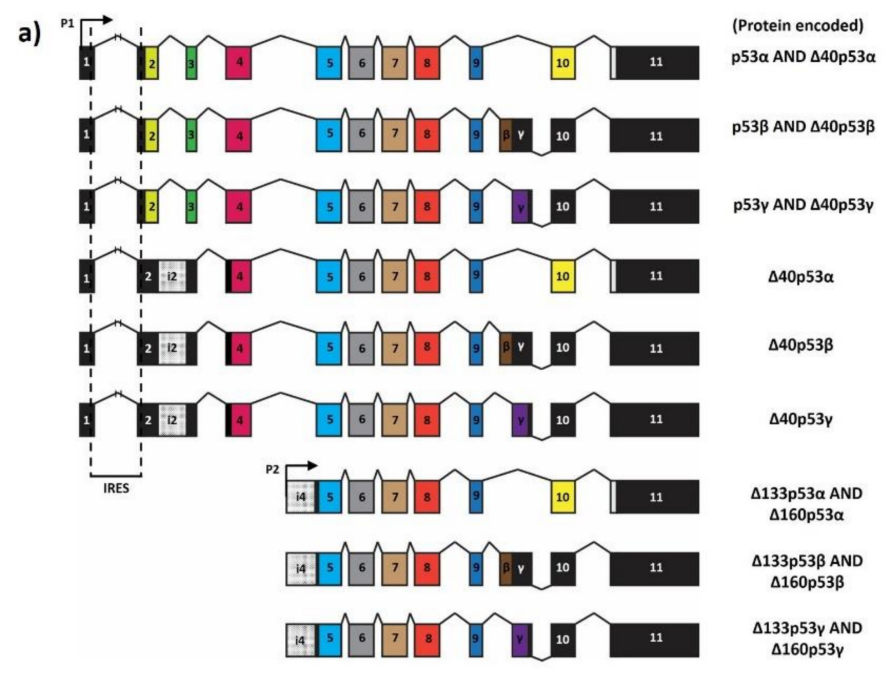

b)

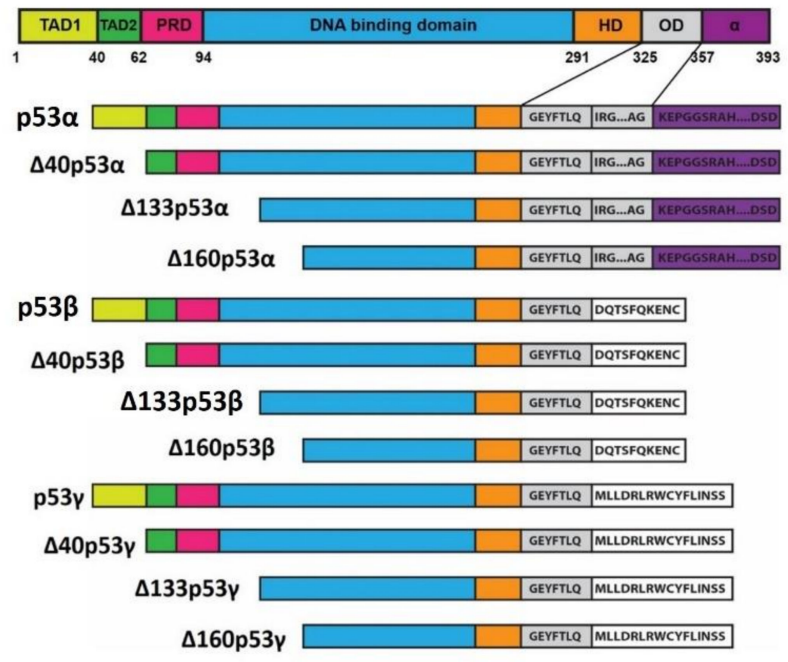

Figure 1. (a) p53 mRNAs. The TP53 gene encodes 9 mRNA transcripts. (b) Functional domains of p53 and its isoforms. p53 contains seven functional domains which are the transactivation domain 1 (TAD1), the transactivation domain 2 (TAD2), the proline-rich domain (PRD), the DNA binding domain (DBD), the hinge domain (HD), the oligomerization domain (OD) and the negative regulation domain $(\alpha)$. At its N-terminus, lies an intrinsic disorder region (IDR) consisting of two acidic trans-activation domains (TAD), TAD1 (residues 1-39) and TAD2 (residues 40-61) and a proline-rich domain (PRD) (residues 62-93). This is followed by a DNA-binding domain (DBD) (residues 94-290) and a hinge domain (HD) (residues 291-324). At its carboxyl terminus, p53 comprises an oligomerization domain (OD) (residues 325-356) and a negative regulation domain ( $\alpha$ ) (residues 357-393). 
The proline-rich domain (PRD) joins TAD2 to the DNA-binding domain (DBD). It contains five PxxP motifs generating SH3 domain binding sites. Proline-rich regions can alter the 3D-structure of a protein though proline isomerisation (PIN1, cyclophilins) in the process regulating the orientation and angles of the interaction of its functional domains [39]. The length of the PRD and prevalence of specific docking sites within suggest an underlying function as a spacer or a scaffolding module necessary for the tumour suppressive role of p53 [39-41].

The DBD is the core domain of p53 that directly interact with DNA. It comprises of an immunoglobulin-like $\beta$-sandwich which provides the surface scaffolding for DNA binding [42]. The protein sequence of the p53 DBD contains numerous highly conserved histidine and cysteine whose coordination with $\mathrm{Zn}^{2+}$ or $\mathrm{Mg}^{2+}$, is integral for 553 conformation and DNA-binding activity $[43,44]$. p53 DBD interactions with its N-terminus can contribute to the stability of the p53 tetramer [45]. Mutations in DBD can cause conformational changes and/or alterations in specificity to p53-target DNA sequences. The propensity for carcinogenic mutations residing within this domain underscores its importance in the tumour suppressive and homeostatic functions of p53 [46]. $\Delta 40 p 53$ isoforms retain the complete DBD. In contrast, $\triangle 133$ p53 isoforms lack a portion of first conserved cysteine box of the DBD, and $\triangle 160$ p53 isoforms lack the entire first conserved cysteine box of the DBD. Despite truncations in the DBD, according to a recent publication, $\triangle 133 \mathrm{p} 53$ and $\Delta 160 \mathrm{p} 53$ isoforms can still have a stable 3D conformation [47].

The hinge domain (HD) is a short linker sequence of amino-acids between the DBD and the oligomerisation domain (OD). The HD offers structural flexibility for p53, allowing the binding of p53 response elements [48]. Germline mutations within the HD (R306P) have been associated with the loss of p53-mediated transcriptional activation of genes such as BAX [49]. Studies involving p53 devoid of the HD showed an inability to recognize consensus sequence, suggesting a possible role for the HD in the allosteric regulation of DNA binding [50].

The oligomerisation domain (aa 325-356), as its nomenclature suggests, is integral for the formation of p53 tetramers. The tetramerization process of p53 is best described as the formation of dimers between two primary dimers. The peptide presents within the oligomerisation domain links with another p53 monomer to form a primary dimer. This then assembles with another dimer to form a tetrameric structure that is stabilized by hydrophobic interactions between oligomerisation domains. Recently, lysine residues located within the oligomerisation domain, unessential for p53's tetramerization capability, have been identified to selectively modulate p53-mediated apoptosis and cell-cycle arrest [51,52].

The extreme C-terminus of p53 containing the $\alpha$ domain is, like the TADs, an IDR. The extreme C-terminus domain, rich in positively charged amino acids (e.g., arginine, histidine, lysine) interacts non-specifically with negatively charged nucleic acids (RNA and DNA) [53]. Numerous proteins bind to the C-terminus domain, explaining why missense mutated p53 protein can still be biochemically and biologically active. The proximity of the C-terminus domain to the DNA-binding surfaces located within the DBD offers structural support for interactions with DNA. Additionally, the disordered $\alpha$ domain can form non-specific DNA interactions to allow the linear diffusion of p53 $\alpha$ along DNA or to transfer its movement to another DNA molecule [54]. Most importantly, the $\alpha$ domain like the TAD undergoes a high degree of post-translational modifications (PTMs) which regulate protein degradation, tetramerisation, promoter selectivity and protein-interaction with the RNA-pol II transcriptional machinery [55].

\section{4. p53 Isoforms Function in Concert}

Various methodologies involving overexpression and/or siRNA knockdown in cell lines, or genetically modified animal models of p53 isoform expression have been developed and used to characterize the function of p53 isoforms [22,27]. The discovered biological functions of p53 isoforms include cell-cycle regulation, cell death, cellular senescence, inflammation, cellular invasion, antioxidant response, tissue regeneration and stem cell renewal and differentiation, which are outlined 
in Table 1. These cellular functions of p53 isoforms have been reported in the context of both malignant (including WT and mutant TP53) and non-malignant cells, originating from different tissues (e.g., skin, prostate, colon).

Table 1. p53 isoforms collectively classified according to reported biomolecular functions. Respective cell/animal models used to investigate isoform function is presented in association with observed alteration in protein/gene expression/activity following p53 isoform manipulation. Implicated genes are in italics.

\begin{tabular}{|c|c|c|c|}
\hline $\begin{array}{l}\text { Cellular Function } \\
\text { Involving p53 Isoforms }\end{array}$ & Cell Line/Model(s) Studied & Altered Expression or Activity & Reference \\
\hline \multirow{9}{*}{ Cell cycle regulation } & MRC-5, WI-38 & $\begin{array}{c}m i R-34 a, C D K N 1 A, P A I-1, I G F B P 7 \\
M M P 3, B U B 1, C D C 20\end{array}$ & [56] \\
\hline & CD8+ T lymphocytes & $\begin{array}{l}\text { CD62L, PD-1, LAG-3, IL-6, IL-8, } \\
\text { SRSF3, CD28, CD57 }\end{array}$ & [57] \\
\hline & HGPS fibroblasts & STUB1, CDKN1A, IL-6, IL-8, SRSF3 & [58] \\
\hline & Transgenic mice model & $\begin{array}{l}\text { IGF-1R, IGF-1, Gadd45, PTEN, } \\
\text { MDM2, CDKN1A, IGFBP-3 }\end{array}$ & [59] \\
\hline & Transgenic mice model & p66Shc, G2-M genes & [60] \\
\hline & Transgenic mice model & MDM2, CDKN1A & [61] \\
\hline & HASMCs & EGR1, SRSF1, KLF5, $p 21$ & [62] \\
\hline & $\begin{array}{l}\text { Human neonatal foreskin and } \\
\text { normal prostate tissue }\end{array}$ & CDKN1A, PUMA, NOXA, hTERT & [63] \\
\hline & $129 / \mathrm{SvJ}$ ESCs & CDKN1A, MDM2 & [64] \\
\hline \multirow{10}{*}{ Apoptosis } & MCF7 & SRSF1, p21, BAX & [65] \\
\hline & H1299 & BAX, p21 ${ }^{\text {WAF1 }}$ & [24] \\
\hline & A375 melanoma cells & CDKN1A, PIDD & [66] \\
\hline & Zebrafish model & CDKN1A, MDM2, BCL2L & [67] \\
\hline & Zebrafish model & $C D K N 1 A, B A X, M D M 2, B C L 2 L$ & {$[68]$} \\
\hline & H1299 & $B A X$ & [16] \\
\hline & $\begin{array}{l}\text { HCT116, SW480, LoVo, SW620, } \\
\text { Colo205 }\end{array}$ & RhoB & [69] \\
\hline & Transgenic mice model & ANXA5, TPT1 & [70] \\
\hline & Transgenic mice model & BIRC5, TRAF1 & [61] \\
\hline & $\begin{array}{l}\text { Human neonatal foreskin and } \\
\text { normal prostate tissue }\end{array}$ & $B A X$ & [63] \\
\hline \multirow{4}{*}{ DNA repair } & HGPS fibroblasts & RAD51 & [58] \\
\hline & QSG-7701, Zebrafish model & RAD51, LIG4, RAD52 & [71] \\
\hline & Transgenic mice model & VCP & {$[70]$} \\
\hline & Saos2, HCT116, H1299 & $\mathrm{p} 73$, RAD51, LIG4, RAD52 & [72] \\
\hline \multirow{3}{*}{ Inflammatory response } & Transgenic mice model, SaOS2 & $\begin{array}{c}\text { STAT1, STAT2, OAS1g, IFI47, IFIT2, } \\
\text { CXCL10 }\end{array}$ & [73] \\
\hline & Transgenic mice model & $\begin{array}{c}\text { Alpha-enolase, TNF-alpha, CCT5, } \\
\text { 14-3-3, ALDH2 }\end{array}$ & [70] \\
\hline & Transgenic mice model & $\begin{array}{c}\text { IL-6, IFN-g, TNF-alpha, IL-3, IL5, } \\
\text { STAT1, JUNB }\end{array}$ & [61] \\
\hline Autophagy & HCT116, H1299 & p-PKR, p-elF2 $\alpha, D R A M$ & [74] \\
\hline \multirow{2}{*}{ Pluripotency } & MCF7 & SOX2, OCT3/4, NANOG & [75] \\
\hline & $129 /$ SvJ ESCs & OCT4, GATA-4, NANOG, IGF-1R & {$[64]$} \\
\hline \multirow[t]{3}{*}{ Cellular invasion } & $\begin{array}{c}\text { MDA-MB-231, D3H2LN, MCF7, } \\
\text { LoVo, SW480, SW620, Colo205, } \\
\text { HCT116 }\end{array}$ & E-cadherin, $\beta 1$-integrin & [76] \\
\hline & Transgenic mice model & ITGB7, VCAM1 & [61] \\
\hline & Transgenic mice model, HCT116 & RhoA, IL-6 & [77] \\
\hline
\end{tabular}

The biological functions of p53 isoforms are influenced by the expression of other isoforms. The retroviral expression of $\mathrm{p} 53 \beta$ in human fibroblasts inhibited cell proliferation and promoted 
cellular senescence via the upregulation of $\mathrm{p} 21^{\mathrm{WAF} 1}$ and miR-34. However, this effect was not observed in TP53-null MDAH041 fibroblasts with hemizygous 1bp deletion at codon 184 (GAT-GAA, ter 244) [78], indicating that $\mathrm{p} 53 \beta$ does not induce senescence on its own but through cooperation with other isoforms produced by the TP53 gene. Similarly, $\triangle 133$ p53 $\alpha$ isoforms' pro-proliferative activity in WT TP53 fibroblasts was not observed in TP53-null MDAH041 fibroblasts $[16,56,57,65]$. If some actions of p53 isoforms are only observed in the presence of other isoforms, it is of merit to investigate their biophysical interactions mediating cooperative behaviour.

The interactions between p53 isoforms can be direct (e.g., formation of homo-oligomers or hetero-oligomers) or indirect (e.g., promoter-dependent oligomerisation) to convey and translate cell signalling in a defined cell response (Figure 2).

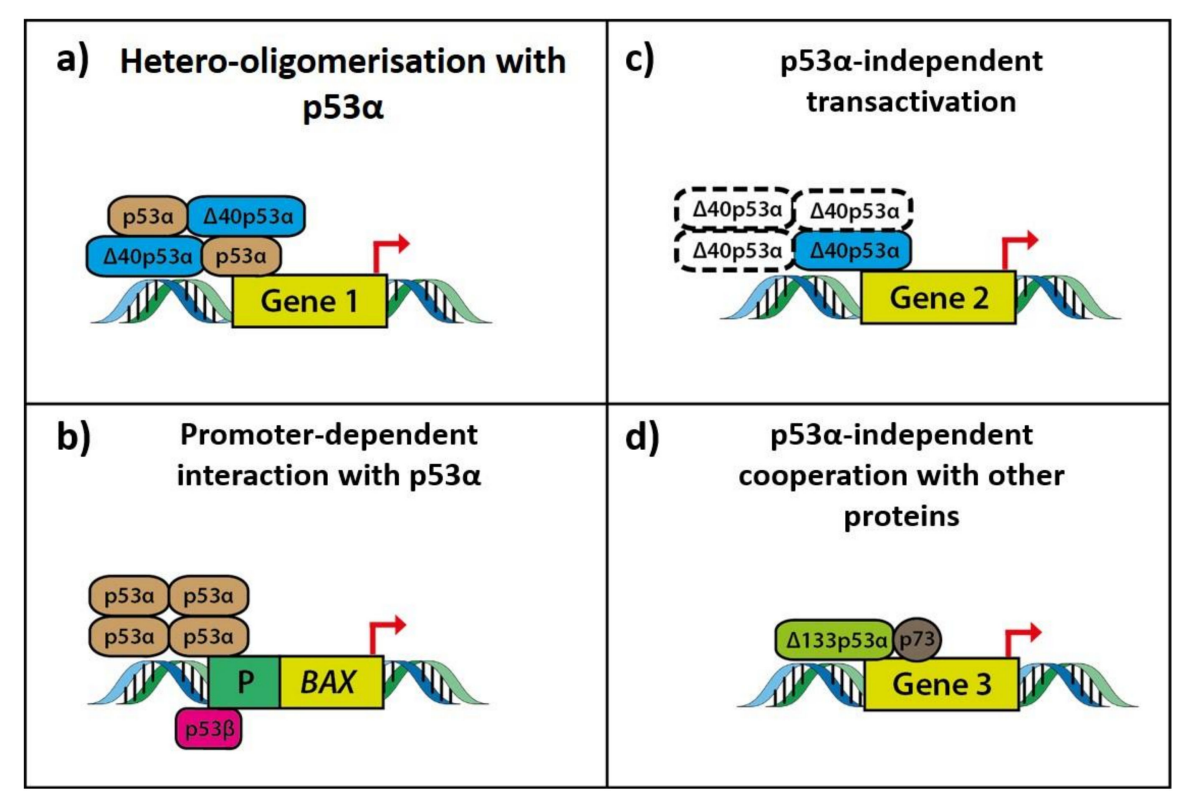

Figure 2. Schematic overview of p53 isoform interactions mediating transactivation. (a) p53 isoforms can form hetero-oligomers with $\mathrm{p} 53 \alpha$ to mediate transactivation. For example, $\Delta 40 \mathrm{p} 53 \alpha / \mathrm{p} 53 \alpha$ hetero-oligomers can modulate the transcriptional activity of promoters of IGF1-receptor and Nanog, thus controlling the switch from pluripotency to differentiation [64]. (b) p53 isoforms can transactivate target genes only in the presence of $\mathrm{p} 53 \alpha$. For example, $553 \beta$ can indirectly interact with p $53 \alpha$ in the presence of the $B A X$ promoter DNA, modulating its promoter activity. Endogenous p $53 \beta$ binds to the $B A X$ promoter in MCF7 cells; however, the exact $\mathrm{p} 53 \beta$ binding sequence on the $B A X$ promoter remains to be elucidated [16]. (c) p53 isoforms can independently mediate transactivation. $\triangle 40 \mathrm{p} 53 \alpha$ can transactivate $B A X$ and GADD45 in p53-null cells; however, whether $\triangle 40 \mathrm{p} 53 \alpha$ mediates transactivation as an oligomeric complex remains unclear (represented by dotted lines) [24]. (d) p53 isoforms can mediate transactivation via cooperation with other proteins. $p 73$ and $\Delta 133 p 53 \alpha$ isoforms can cooperate in a p53-null environment to mediate DNA repair [72].

Although the canonical oligomerisation domain, required for the direct interaction and formation of hetero-oligomers with $\alpha$-isoforms, is partially deleted in p $53 \beta$ isoforms, they can indirectly interact with $\mathrm{p} 53 \alpha$ in the presence of the $B A X$ promoter DNA (co-immunoprecipitation of p53 $\beta$ and p53 $\alpha$ in presence of $B A X$ promoter in $\mathrm{H} 1299$ cells co-transfected with $\mathrm{p} 53 \alpha$, p53 $\beta$ and Bax-luciferase reporter plasmid) modulating its promoter activity [16,79]. In contrast, $\Delta 40 \mathrm{p} 53 \alpha$ and $\Delta 133 \mathrm{p} 53 \alpha$ isoforms which retain the complete oligomerisation domain can directly interact with p53 $\alpha$ (and probably other $\alpha$-isoforms) to form distinct permutation of hetero-oligomers, which would differentially expose amino-acid domains to protein partners (i.e., $\mathrm{Mdm} 2, \mathrm{MDMx}$ ) or cell protein machineries (i.e., transcriptional machinery, splicing machinery, microRNA machinery). $\Delta 40 \mathrm{p} 53 \alpha / \mathrm{p} 53 \alpha$ complexes can mediate biological responses by modulating the transcriptional activity of promoters of IGF1-receptor 
and Nanog, thus controlling the switch from pluripotency to differentiation $[24,64,80]$. In A375 melanoma cells, $\triangle 40 \mathrm{p} 53 \alpha / \mathrm{p} 53 \alpha$ complexes had modified promoter activity at $L R D D$ and CDKN1A genes contributing to shifting cell-fate outcome in favour of apoptosis compared to cell-cycle arrest (upregulation of PIDD and downregulation of p21) despite exposure to $\gamma$-irradiation, an established trigger for p53-mediated DNA damage and cell cycle arrest [66].

Via direct hetero-oligomerisation, it has been reported that $\Delta 133 \mathrm{p} 53 \alpha$ can exert a dominant-negative effect on the apoptotic actions of p53 $\alpha$ to favour p53 dependent DNA-repair and cell cycle progression [56]. Recently, von Muhlinen et al. coimmunoprecipitated p53 $\alpha$ with overexpressed FLAG-tagged $\Delta 133 \mathrm{p} 53 \alpha$ and concomitantly observed decreased expression of p21 mRNA and miR-34a mRNA, consistent with the dominant-negative inhibition of p53 $\alpha$-mediated cell senescence [58]. However, the dominant-negative effect of $\Delta 133 \mathrm{p} 53 \alpha$ on p $53 \alpha$ is not universally observed and therefore, is likely to be context and DNA-sequence dependent. In U2OS cells, the induction of $\Delta 133 p 53 \alpha$ inhibited p53 $\alpha$-dependent apoptosis and G1 arrest but not p53 $\alpha$-dependent G2 arrest [81]. Similarly, instead of an exclusively dominant-negative relationship, the differential regulation (promoter and stress-dependent) of $\Delta 113$ p53 $\alpha$ on p53 was observed in zebrafish [66]. Factors contributing to this selective modulation of $\mathrm{p} 53 \alpha^{\prime} \mathrm{s}$ transcriptional activity remain unclear. Furthermore, the functional significance of hetero-oligomers comprising of two or more types of p53 isoforms including/excluding p $53 \alpha$, has yet to be explored.

The effect of hetero-oligomerisation of isoforms can be dose-dependent, therefore influenced by the relative expression levels of the different isoforms. $\Delta 40 \mathrm{p} 53 \alpha$ at low levels increased p53 $\alpha^{\prime} \mathrm{s}$ transactivation capacity, but at higher levels, inhibited p53 $\alpha$ 's anti-proliferative effects [80]. Tetramers consisting of p53 $\alpha$ and $\Delta 40 \mathrm{p} 53 \alpha$ isoforms were a more stable complex compared to a purely p53 $\alpha$ complex [82]. One possible mechanism is that the $\triangle 40 \mathrm{p} 53 \alpha$ isoforms lack TAD1 precluding them from MDM2 mediated degradation [21,24]. The actions of MDM2 in the regulation of basal levels of p53 $\alpha$ is in two ways. Firstly, MDM2 drives the translocation of $\mathrm{p} 53 \alpha$ from the nucleus to the cytoplasm for proteasomal degradation. Alternatively, MDM2 can induce the ubiquitination of p $53 \alpha$ to unmask the nuclear export signal located in the oligomerisation domain of $\mathrm{p} 53 \alpha$, making it more susceptible to nuclear export and degradation [83]. The p53 isoforms themselves have varied subcellular localization patterns possibly altering their susceptibility to MDM2 mediated degradation [16]. $\Delta 40 \mathrm{p} 53 \alpha$ isoforms, in particular, have been preferentially found in the nucleus [84]. Indeed, MDM2 can distinguish between p53 isoforms and differentially mediate their ubiquitination and degradation [85]. Hence, it is possible that the susceptibility of p53 hetero-oligomers to regulatory proteins such as MDM2 is dependent on the isoform composition adding a layer of permutation to the p53 response.

Some p53 isoforms can bind to p53-response elements to induce the p53 mediated response. $\triangle 40 \mathrm{p} 53 \alpha$ can bind and transactivate independently of p53 $\alpha$ some genes such as MDM2, BAX and GADD45 genes [24]. $\triangle 133 \mathrm{p} 53 \alpha$ isoforms can in response to $\gamma$-radiation upregulate the transcription of DNA double-strand break repair genes including RAD51, RAD52 and LIG4 by binding to a novel type of p53-responsive element in their promoters independently of p53 $\alpha$ [71]. Alternatively, p53 isoforms can, by directly interacting or cooperating with other proteins, exert their p $53 \alpha$ independent cellular effects. $\Delta 133 \mathrm{p} 53 \beta$ isoforms can interact with the anti-apoptotic protein, small GTPase RhoB, to negatively regulate RhoB activity inhibiting apoptosis [69]. Vascular smooth muscle proliferation has been found to be promoted by SRSF1, via the induction of $\triangle 133$ p53a isoforms which in turn complexes with EGR1 to activate KLF5-p21 signalling [62]. In p53 deficient H1299 cells, the increased DNA double-strand break repair was associated with the overexpression of $\Delta 133 p 53 \alpha$ isoforms and was reduced upon knockdown of p73. The changes in the levels of the latter alone had no effect of DNA double-strand break repair suggesting that $\mathrm{p} 73$ and $\Delta 133 \mathrm{p} 53 \alpha$ isoforms can cooperate in a $\mathrm{p} 53 \alpha$ -null environment to upregulate the transcription of DNA double-strand break repair genes including RAD51, RAD52 and LIG4 [71,72].

Next, the question emerges as to which p53 mediated biological activities are p53 $\alpha$-dependent and which ones are instead, influenced independently of p $53 \alpha$ by the other isoforms. This has significant 
biological implications, as for example, a mutation upstream of codon 133, excluding promoter and splice site mutations, will unalter $\Delta 133 \mathrm{p} 53 \alpha$ mediated DNA repair but may perturb other p53-mediated functions reliant on WT upstream domains (i.e., apoptosis). Hence, it is conceivable that upon a TP53 mutational event and the consequential abrogation of p $53 \alpha$-response, unaffected WT p53 isoforms can continue to exert their p $53 \alpha$-independent cellular effects influencing the severity of the consequential carcinogenic process (Figure 3).

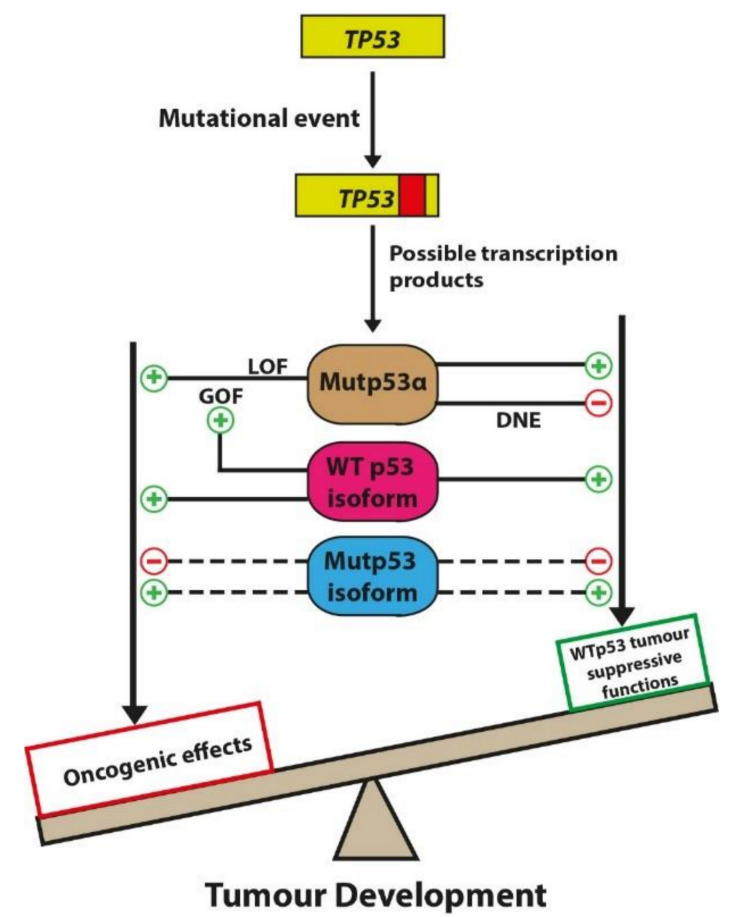

Figure 3. A TP53 mutational event can result in the generation of Mutp53 $\alpha$, WTp53 and Mutp53 isoform. Mutp $53 \alpha$ can mediate tumorigenesis via the following mechanisms: loss of WTp53 activity by dominant-negative effect (DNE) over the WTp53 allele. Alternatively, Mutp53 $\alpha$ via gain of function (GOF) mutations promote oncogenic effects in a cell context-dependent manner [86]. WTp53 isoforms can contribute to tumour suppressive functions (e.g., $\Delta 133 \mathrm{p} 53 \alpha$ isoforms can coordinate with p73 to mediate DNA repair) and may also possess intrinsic oncogenic functions (e.g., $\Delta 133$ p $53 \beta$ isoforms mediating angiogenesis). Preliminary evidence also suggests that WTp53 isoforms $(\Delta 160 \mathrm{p} 53 \alpha)$ can contribute to the GOF effects of Mutp53 $\alpha$ [87]. The function of Mutp53 isoform in tumorigenesis remains unclear (represented by dotted lines) but, could theoretically mediate both oncogenic and tumour suppressive effects. Together this provides an overview of the possible downstream p53 isoform effects following a TP53 mutational event.

p53 isoforms were observed to exhibit paradoxical effects, such as promoting both cellular proliferation and apoptosis, albeit in different cellular contexts. For example, p $53 \beta$ induces cellular senescence in normal human fibroblasts, CD8+ T lymphocytes and MCF7 cells but promoted cellular proliferation in the latter upon treatment with TG003 [65]. To guard cellular homeostasis, spatiotemporal interactions between p53 isoforms (e.g., hetero-oligomerisation), can mediate a non-binary, robust cellular response algorithm (to a physiological or external stimulus; e.g., DNA damage, virus) which remains inadequately understood, contributing to the perceived paradox. Therefore, it would be an oversimplification to merely classify individual p53 isoforms as either exclusively being tumour suppressors or oncogenes [57,65].

In replicative senescent cells, the expression of p53 $\beta$ was increased and $\Delta 133 p 53 \alpha$ decreased in comparison to non-senescent cells [56]. The significance of protein isoform imbalance contributing to pathology has been previously recognized, most notably in tauopathies. A shift in the normal 
balance of tau isoforms ( $3 R$ and $4 R$ ) in the human brain has been associated with abnormal neuronal firing and cognitive impairment. Modulating the tau isoform imbalance with RNA reprogramming (trans-splicing strategy) was associated with reduced accumulation of pathological tau and is therefore regarded as a promising therapeutic strategy for neurodegenerative diseases and may possess similar therapeutic value for pathology associated with p53 isoform imbalance [88]. Investigating therapeutics at the protein level, Lei at al. showed evidence of p53 isoform modulation via introducing a p53 peptide (107-129) to stabilise and shift the conformation of $\Delta 133 \mathrm{p} 53 \beta$ to that of WT p53 [47]. However, whether the functional effects of $\Delta 133 \mathrm{p} 53 \beta$ have been altered remain to be studied. This strategy albeit preliminary may be of value in malignant pathology with increased expression of $\Delta 133 \mathrm{p} 53 \beta$, associated with cancer invasiveness (discussed in the next section).

\section{5. p53 Isoforms in Cancer}

Dysregulation of p53 isoform co-expression may alter, without abolishing, the predicted p53 response, therefore driving carcinogenesis while simultaneously conferring sensitivity to a type of cancer treatment. Several studies have attempted to investigate the expression of p53 isoforms in both cancerous and normal tissues, largely utilizing RT-qPCR based assays. From these studies, it is apparent that p53 isoform expression is not random (Table 2). In breast tumours, Gadea et al. reported that $\Delta 133 p 53 \alpha$ was co-expressed with other isoforms including $\Delta 133 p 53 \gamma$ and $\Delta 133 p 53 \beta$ [76]. In head and neck squamous cell cancer, p $53 \beta$ was found to be consistently overexpressed in almost all samples investigated and $\Delta 133$ p53 isoforms were overexpressed in non-small cell lung cancer compared to adjacent normal tissue $[89,90]$. The non-random, isoform co-expression was also observed in premalignant tissue, where $\mathrm{p} 53 \beta$ was elevated and $\Delta 133 \mathrm{p} 53 \alpha$ reduced in colonic adenoma in contrast to normal or non-adenoma tissue [56].

Table 2. Summary of p53 isoform expression and associated clinicopathologic outcomes in human cancers. $n$ refers to the number of patients from whom the samples analysed were obtained from each study. Cholangiocarcinoma (CCA); glioblastoma (GBM); renal cell carcinoma (RCC); uterine squamous cell carcinoma (USC); acute myeloid leukaemia (AML); squamous cell carcinoma of head and neck (SCCHN); endometrial carcinoma (EC).

\begin{tabular}{|c|c|c|c|c|}
\hline Cancer & Isoforms Studied & $\mathbf{N}$ & Summary of Key Results & References \\
\hline \multirow{6}{*}{ Breast } & $\begin{array}{c}\Delta 133 p 53 \alpha \\
\Delta 133 p 53 \beta / \gamma\end{array}$ & 147 & $\begin{array}{l}\text { Inverse association in expression of } \Delta 133 \mathrm{p} 53 \beta \text { mRNA with } \\
\text { p } 68 \text { protein. }\end{array}$ & [91] \\
\hline & $\begin{array}{l}\mathrm{p} 53 \beta, \Delta 40 \mathrm{p} 53 \mathrm{a} \\
\Delta 133 \mathrm{p} 53 \beta\end{array}$ & 47 & $\begin{array}{c}\Delta 133 p 53 \beta \text { isoform increased in invasive breast carcinomas } \\
\text { compared to non-invasive cases. }\end{array}$ & [92] \\
\hline & $\begin{array}{l}\mathrm{p} 53 \beta / \gamma, \Delta 40 \mathrm{p} 53 \alpha \\
\Delta 133 \mathrm{p} 53 \alpha\end{array}$ & 148 & $\begin{array}{c}\Delta 40 \mathrm{p} 53 \text { was increased in tumour breast tissue and associated } \\
\text { with aggressive subtype. p53 } 3 \text { expression was associated with } \\
\text { poorer disease-free survival. }\end{array}$ & [93] \\
\hline & $\Delta 133 \mathrm{p} 53 \alpha / \beta / \gamma$ & 273 & $\begin{array}{l}\Delta 133 p 53 \beta \text { reduced in HER2 positive tumours and is associated } \\
\text { with poorer disease-free and overall survival }\end{array}$ & [76] \\
\hline & $\mathrm{p} 53 \beta / \gamma$ & 127 & $\begin{array}{l}\text { Mutant p53 breast tumour-expressing p53 } \gamma \text { isoform had } \\
\text { improved disease-free survival. p } 53 \beta \text { was associated with } \\
\text { tumour oestrogen receptor (ER) expression }\end{array}$ & [94] \\
\hline & $\Delta 40 \mathrm{p} 53 \alpha$ & 139 & $\begin{array}{c}\text { Reduced } \Delta 40 \mathrm{p} 53 \alpha: \mathrm{p} 53 \text { ratio associated with improved } \\
\text { disease-free survival. }\end{array}$ & [95] \\
\hline \multirow{4}{*}{ Ovarian } & $\begin{array}{r}\Delta 40 \mathrm{p} 53 \alpha \\
\Delta 133 \mathrm{p} 53 \alpha\end{array}$ & 169 & $\begin{array}{c}\text { No difference in p53 isoform expression between stage I and III } \\
\text { ovarian cancer. }\end{array}$ & [96] \\
\hline & $\begin{array}{r}\Delta 40 \mathrm{p} 53 \alpha \\
\Delta 133 \mathrm{p} 53 \alpha\end{array}$ & 166 & $\begin{array}{c}\Delta 40 \mathrm{p} 53 \alpha \text { expression associated with improved disease-free } \\
\text { survival in patients with mucinous ovarian cancer with WT } \\
\text { TP53. Increased } \Delta 133 \mathrm{p} 53 \text { expression in endometroid } \\
\text { ovarian cancer. }\end{array}$ & [97] \\
\hline & $\begin{array}{r}\Delta 40 \mathrm{p} 53 \alpha \\
\Delta 133 \mathrm{p} 53 \alpha\end{array}$ & 154 & $\begin{array}{c}\Delta 133 p 53 \text { expression associated with improved disease-free and } \\
\text { overall survival in p53 mutant serous ovarian cancer. Increased } \\
\Delta 40 \text { p53 expression associated with improved disease-free } \\
\text { survival but not overall survival in p53 WT serous } \\
\text { ovarian cancer. }\end{array}$ & [98] \\
\hline & $\begin{array}{l}\mathrm{p} 53 \alpha / \beta / \gamma \\
\Delta 133 \mathrm{p} 53 \alpha\end{array}$ & 69 & $\begin{array}{l}\text { No difference in isoform expression between chemo responders } \\
\text { and non-chemo responders. Increased } \Delta 133 \mathrm{p} 53 \alpha \text { expression } \\
\text { significantly associated with improved overall survival and } \\
\text { borderline significance for improved disease-free survival. }\end{array}$ & [99] \\
\hline
\end{tabular}


Table 2. Cont

\begin{tabular}{|c|c|c|c|c|}
\hline Cancer & Isoforms Studied & $\mathbf{N}$ & Summary of Key Results & References \\
\hline \multirow[t]{2}{*}{ Colon } & $\mathrm{p} 53 \beta, \Delta 133 \mathrm{p} 53 \alpha$ & 29 & $\begin{array}{c}\text { Colon adenoma tissues expressed elevated } p 53 \beta \text { and reduced } \\
\Delta 133 p 53 \alpha \text { expression compared with non-adenoma and normal } \\
\text { colon tissue. } \Delta 133 \mathrm{p} 53 \text { isoform expression was significantly } \\
\text { higher in carcinoma tissue }\end{array}$ & [56] \\
\hline & $\Delta 133 \mathrm{p} 53 \alpha / \beta$ & 35 & $\begin{array}{c}\text { Increased } \Delta 133 p 53 \alpha \text { expression associated with poorer } \\
\text { disease-free survival. }\end{array}$ & [77] \\
\hline CCA & $\Delta 133 p 53 \alpha$ & 48 & $\begin{array}{c}\text { Increased } \Delta 133 \mathrm{p} 53 \text { and } \Delta 133 \mathrm{p} 53 / \mathrm{p} 53 \mathrm{a} \text { expression associated } \\
\text { with a poorer overall survival. }\end{array}$ & [100] \\
\hline \multirow[t]{2}{*}{ GBM } & $\Delta 40 \mathrm{p} 53 \alpha, \mathrm{p} 53 \beta$ & 17 & $\begin{array}{l}\Delta 40 \mathrm{p} 53 \alpha \text { was observed in glioblastoma tissue which was not } \\
\text { detected in non-tumour cerebral cortex. }\end{array}$ & [101] \\
\hline & $\begin{array}{l}\mathrm{p} 53 \beta, \Delta 40 \mathrm{p} 53 \alpha \\
\quad \Delta 133 \mathrm{p} 53 \alpha\end{array}$ & 89 & $\begin{array}{l}\triangle 133 \text { p } 53 \beta \text { expression increased on a wild-type TP53 } \\
\text { background in glioblastoma. }\end{array}$ & [102] \\
\hline \multirow{3}{*}{ RCC } & $\begin{array}{c}\mathrm{p} 53 \beta / \gamma, \\
\Delta 133 \mathrm{p} 53 \alpha / \beta / \gamma\end{array}$ & 41 & $\begin{array}{l}\text { p53 } \beta \text { mRNA was overexpressed in tumour samples and } \\
\text { correlated with tumour stage. }\end{array}$ & [103] \\
\hline & $\mathrm{p} 53 \beta / \gamma$ & 268 & $\begin{array}{l}\text { p53 } \beta \text { expression was associated with improved disease-free and } \\
\text { overall survival in p53 mutant patients. }\end{array}$ & [104] \\
\hline & $\begin{array}{l}\mathrm{p} 53 \alpha, \Delta 40 \mathrm{p} 53 \alpha \\
\quad \Delta 133 \mathrm{p} 53 \alpha\end{array}$ & 41 & $\begin{array}{l}\text { Expression of } \mathrm{p} 53 \mathrm{p} 53 \alpha, \Delta 40 \mathrm{p} 53 \alpha, \Delta 133 \mathrm{p} 53 \alpha \text { was increased in } \\
\text { mutant TP53 RCC compared to WT TP53 RCC. }\end{array}$ & [105] \\
\hline EC & $\begin{array}{c}\mathrm{p} 53 \beta / \gamma, \Delta 40 \mathrm{p} 53 \alpha \\
\Delta 133 \mathrm{p} 53 \alpha\end{array}$ & 37 & $\begin{array}{l}\text { Increased p53 } \gamma \text { expression is associated with poorer } \\
\text { disease-free survival }\end{array}$ & [106] \\
\hline AML & $\mathrm{p} 53 \beta / \gamma$ & 68 & $\begin{array}{l}\text { p53 } 3 \text { and p53 } \gamma \text { expression correlated with mutated NPM1, } \\
\text { a marker of improved overall survival. }\end{array}$ & [107] \\
\hline SCCHN & $\begin{array}{c}\mathrm{p} 53 \beta / \gamma \\
\Delta 133 \mathrm{p} 53 \alpha / \beta / \gamma\end{array}$ & 21 & $\mathrm{p} 53 \beta / \gamma, \Delta 133 \mathrm{p} 53 \alpha / \beta / \gamma$ were detected in tumour tissue. & [89] \\
\hline Lung & $\Delta 133 p 53 \alpha$ & 17 & $\begin{array}{l}\text { Overexpression of } \Delta 133 \mathrm{p} 53 \mathrm{mRNA} \text { was observed in cancerous } \\
\text { tissue as compared to adjacent non-cancerous tissue. }\end{array}$ & [90] \\
\hline Melanoma & $\begin{array}{c}\mathrm{p} 53 \alpha / \beta / \gamma \\
\Delta 40 \mathrm{p} 53 \alpha / \beta / \gamma \\
\Delta 133 \mathrm{p} 53 \alpha / \beta / \gamma \\
\Delta 160 \mathrm{p} 53 \alpha\end{array}$ & 38 & $\begin{array}{l}\text { In tumour tissue, } \Delta 40 p 53 \beta \text { expression was reduced, whereas } \\
\Delta 133 \mathrm{p} 53 \alpha \text { and } \Delta 160 \mathrm{p} 53 \alpha \text { expression was increased. Reduced } \\
\text { p53 } 3 \text { expression or increased } \Delta 133 \mathrm{p} 53 \beta \text { and p53 } 3 \alpha \text { mNA } \\
\text { expression were associated with poorer overall survival. }\end{array}$ & [108] \\
\hline
\end{tabular}

Up to now, clinical studies have largely investigated one isoform at a time, however, it is becoming clear that the p53 isoforms are co-expressed and work in concert to define cellular responses. Therefore, to better understand p53 isoform activities, future studies evaluating the relationship between p53 isoform expression and clinical outcomes should adopt investigating the co-expression of the different p53 isoforms in combinations.

The increased expression of $\mathrm{p} 53 \beta$ has been associated with improved disease-free survival in breast and clear cell renal cell carcinoma $[93,104]$. In cancer cell lines and normal fibroblasts endogenously co-expressing p53 isoforms, the overexpression of p53 $\beta$ induces apoptosis and cell senescence via the upregulation of genes such as $B A X$ and $p 21 / m i R 34$ in a p53-dependent manner [56]. The tumour suppressive effects observed in cell studies may explain the improved cancer outcomes associated with the expression of $\mathrm{p} 53 \beta$. The expression of the alternate C-terminal variant $\mathrm{p} 53 \gamma$, with other isoforms, is predominantly associated with reduced risk of cancer progression as reported in breast and uterine squamous cell carcinoma [94,106].

The expression of $\Delta 40 \mathrm{p} 53 \alpha$ is higher in tumours than normal tissue in both glioblastoma and breast cancer $[93,101]$. The clinically more aggressive triple-negative breast cancer subtype is associated with increased $\Delta 40 p 53 \alpha$ expression [93]. Contrastingly, in mucinous ovarian cancer, the expression of $\Delta 40 \mathrm{p} 53 \alpha$ is associated with improved disease-free survival [97]. Taking this together, the biological relevance of $\Delta 40 \mathrm{p} 53 \alpha$ is evident, however, it is not possible to attribute to it an absolute oncogenic or tumour suppressive role since its activity is dependent on cell function, cell context and the co-expressed driver oncogenes.

The overexpression of $\Delta 133 \mathrm{p} 53 \alpha$ in tumour tissue has been reported in cholangiocarcinoma, lung, colon and ovarian cancers $[56,90,98,100]$. In lung cancer tissue, p21 expression was reduced whereas $\Delta 133$ p53 $\alpha$ was overexpressed, however, this inverse relationship did not reach statistical significance possibly owing to the small sample size [90]. Further evidence of this relationship is observed in breast cancer, where $\Delta 133 \mathrm{p} 53 \alpha$ inhibits the ability of p68 to induce p53-dependent transcription from the $p 21$ promoter [91]. This suggests that tumour cells with $\Delta 133 p 53 \alpha$ expression could have reduced ability to undergo p21 mediated cell-cycle arrest. Increased $\Delta 133 \mathrm{p} 53 \alpha$ isoform expression, in the context 
of WT TP53, has been associated with poorer disease-free survival in patients with colorectal cancer. A possible mechanism explaining this association is $\Delta 133$ p $53 \alpha$ isoform mediated tumour cell invasion via increased IL-6 expression activating JAK-STAT3 and RhoA-ROCK pathways [77]. Interestingly, in advanced serous ovarian cancer tissue with mutant TP53 gene, $\triangle 133 p 53 \alpha$ expression was associated with improved disease-free survival and overall survival, providing preliminary evidence that the mutational status of TP53 can influence the association between p53 isoform expression and patients' clinical outcome.

In breast cancer, $\Delta 133 \mathrm{p} 53 \beta$ expression was significantly associated with an increased risk of cancer recurrence and poorer overall survival $[76,92]$. In HCT116 cells, $\Delta 133 p 53 \beta$ expression was found to promote the acquisition of an amoeboid-like phenotype associated with epithelial mesenchymal transition and cell invasiveness [76]. Recently Kazantseva et al. showed that the expression of $\Delta 133 \mathrm{p} 53 \beta$, which was increased in glioblastoma tissues with WT p53, promoted an immunosuppressive tumour microenvironment by increasing CCL2 expression and subsequent CD163 macrophage infiltration [102]. Taken together, it is becoming apparent that $\Delta 133 \mathrm{p} 53 \beta$ co-expression with other $\mathrm{p} 53$ isoforms could be associated with poorer cancer outcomes.

The expression and cellular effects of p53 isoforms can be influenced by the mutational status of TP53. Therefore, it is recommended that the p53 isoform expression is reported with respect to the mutational status of TP53, to establish more precise correlations with clinical outcomes $[109,110]$. However, stating whether p53 is WT or mutant may not suffice as it is becoming apparent that the mutational landscape of p53 is highly heterogeneous and the various p53 mutants are not equal in their cellular and phenotypical effects [111,112]. For example, Li Fraumeni syndrome (LFS) patients with specific p53 DBD mutations (associated with impaired anti-proliferative functions in H1299 cultured cells) have tumour incidences at an earlier age compared to LFS patients harbouring germline TP53 mutations retaining anti-proliferative functions [112].

A feasible step towards representing p53 isoform expression in relation to the heterogeneous p53 mutations would be to adopt a functional-domain oriented approach by classifying p53 mutants as follows: TAD, oligomerisation domain and DBD mutants [113]. Studies investigating mutations (missense mutations, insertions and deletions) within the TAD of p53 revealed that these mutations often introduce a stop codon upstream of the ATG codon in exon 4, disrupting the expression of p53 $\alpha$. These mutants, classified as TAD mutants of p53, consequentially express all p53 isoforms except p53 $\alpha$, $\mathrm{p} 53 \beta$ and $\mathrm{p} 53 \gamma$. As these mutants still possess the ability to partially transactivate p53-dependent genes, including pro-apoptotic genes, TAD mutants could be generally more responsive to treatment and associated with a better prognosis than DBD mutants [113,114]. The impact of a mutation in the exons coding for the oligomerisation domain and DBD on the expression of p53 isoforms is less clearly defined as compared to that of TAD mutants.

Select p53 isoforms are often studied in isolation, leaving the implications of any potential changes in other isoforms unclear. As a type of p53 isoform is never expressed exclusively as a single p53 protein in cancer or normal cells, characterisation of their combined activities is required to recapitulate physiological expression. Nutthasirikul et al. identified that the $\Delta 133 \mathrm{p} 53 \alpha / \mathrm{p} 53 \alpha$ ratio was an independent predictor of poor prognosis in intrahepatic cholangiocarcinoma [100]. A lower $\Delta 40$ p53 $\alpha$ :p53 $\alpha$ ratio was associated with reduced cancer progression in breast cancer [95]. With consistent associations being observed (e.g., p53 $\beta$ expression correlating with a better prognosis), a concerted effort to decipher how the combined co-expression of various isoforms and type of p53 mutation alter cancer prognosis and survival is required.

\section{Implications of $\mathrm{p} 53$ Isoforms Beyond Cancer}

The role of p53 in embryological development has been a perplexing puzzle that has not yet been fully understood, and more than one type of p53 isoform has been implicated. p53 null mouse, zebrafish and drosophila models have been developed showing different embryogenic abnormalities and also possess a phenotype characterized by an increased incidence of cancers at an earlier age [115-119]. 
When p53 was overexpressed or hyperactivated in transgenic animal models, embryonic defects were observed with consequential phenotype influenced by the magnitude and spatiotemporal pattern of p53 activation [120]. In mouse models with TP53 expressing $\Delta 122$ p53, isoforms (equivalent to human $\Delta 133 \mathrm{p} 53$ ) were associated with abnormalities in embryogenesis, with a predilection for female embryos. These include exencephaly, ophthalmoplegia, ectopic vertebrae and foetal reabsorption [31]. In zebrafish, the loss of function mutation in the Def gene impaired digestive organ growth and induced the expression of the Z $\Delta 113 \mathrm{p} 53 \alpha$ isoform [115]. This suggests that in the zebrafish Z $\Delta 113 \mathrm{p} 53 \alpha$ isoforms are negatively regulated by the Def gene during embryogenesis to avoid dysregulation of organogenesis. Taken together, these indicate that the $\mathrm{Z} \Delta 113 \mathrm{p} 53 \alpha$ isoforms could have a role in normal embryogenesis and whether this is p53 $\alpha$ dependent remains unclear [30].

Transgenic mice ectopically expressing $\Delta 40 \mathrm{p} 53 \alpha$ isoform in the presence of WT p53 had a progeroid phenotype consistent with accelerated ageing (reduced bone mineral density and loss of fertility). The disrupted $\Delta 40 \mathrm{p} 53 \alpha$ :p53 $\alpha$ isoform ratio in these mice was associated with the upregulation of IGF-1 signalling [59]. $\triangle 40 \mathrm{p} 53 \alpha$ isoforms functionally inactivate PTEN which regulates IGF signal transduction to Akt, thus dysregulating IGF-1 signalling and consequentially promoting cellular senescence and reduced proliferation. Glucose homeostasis was also adversely affected in $\Delta 40 \mathrm{p} 53 \alpha$ transgenic mice, characterized by early-onset hyperinsulinemia and glucose intolerance, resulting in hyperglycaemia and impaired proliferation of $\beta$-cells in the pancreas. Abnormal $\beta$-cell growth homeostasis could be a result of dysregulated Akt regulation of CDK4, cyclin D1 and cyclin D2 via the effects $\Delta 40 \mathrm{p} 53 \alpha$ isoforms on IGF1 signalling [121]. In the rare progeria disease, Hutchinson-Gilford progeria syndrome (HGPS), the premature ageing phenotype has been associated with the overexpression of $\mathrm{p} 53 \beta$ and the reduction of $\Delta 133 \mathrm{p} 53 \alpha$ isoforms. Further analysis in proliferative HGPS fibroblasts with the depletion of $\Delta 133 \mathrm{p} 53 \alpha$ isoforms was associated with increased mRNA expression of p53 target genes associated with cellular senescence ( $p 21 / C D K N 1 A)$, senescence-associated secretory phenotype (SASP) and pro-inflammatory cytokines (IL-6 and IL-8), hence explaining the progeria phenotype [58].

Ageing is a direct risk factor for neurodegenerative conditions such as Alzheimer's disease. In a mouse model, the overexpression of $\Delta 40 \mathrm{p} 53 \alpha$ isoform, associated with an accelerated ageing phenotype, conferred dysregulated tau phosphorylation and cognitive dysfunction. The mouse $\Delta 40 \mathrm{p} 53 \alpha$ isoform was observed to promote tau phosphorylation via binding to promoters and inducing transcription of several kinases (Dyrk1A, GSK3 $\beta$, Cdk5, p35, and p39) [58]. Overexpression of p53 $\beta$ in WT TP53 expressing cells, consistent with investigations from cancer cell lines, induced senescence in astrocytes. In a state of senescence, cells secrete a host of cytokines, proteases and growth factors that alter the tissue microenvironment [122]. However, when astrocytes are in a state of senescence, the resulting SASP induces neurotoxicity which can be observed with overexpression of $p 53 \beta$ or the knockdown of $\Delta 133 p 53 \alpha$ isoforms. Indeed, in the brain tissue of patients with Alzheimer's disease and amyotrophic lateral sclerosis, p53 $\beta$ was upregulated and $\Delta 133 \mathrm{p} 53 \alpha$ isoforms downregulated compared to age-matched normal brain tissue [123]. More recently, in response to irradiation, $\Delta 133 p 53 \alpha$ isoforms were observed to have a protective role against radiation-induced brain injury (risk of reduced cognitive and vocational ability), via inhibiting senescence and preventing astrocyte-derived neuroinflammation in human astrocytes [123].

p53 isoforms can mediate a chronic pro-inflammatory state similar to disease states observed in autoimmune inflammatory arthropathies and vasculitis. Serum analysis of mice expressing $\Delta 122 p 53$ isoforms revealed increased expression of inflammation-associated cytokines such as IFN $\gamma, \operatorname{TNF} \alpha$, IL6, CCL2 and GM-CSF. When IL-6 was depleted in these mice, fewer tumours were observed and mediators of the JAK-STAT signalling pathway were downregulated, supporting a role for p53 isoform induced inflammation in carcinogenesis [31].

Bacterial and viral exposure is a recognized form of cell stress. Viral infections are especially well-established deregulators of the p53 pathway (e.g., HPV, the Epstein Barr virus or influenza virus). Helicobacter pylori can upregulate the expression of $\Delta 133 \mathrm{p} 53$ isoforms in vivo via activation of transcription factors cFOS/cJun ultimately deregulating $\mathrm{p} 53 \alpha$ [123]. This reduced $\mathrm{p} 53 \alpha$ mediated stress 
response signalling, allowing continued progression of helicobacter pylori-associated pathogenesis and eventually tumorigenesis.

In Drosophila, p53 isoforms can mediate tissue regeneration by influencing apoptosis-induced proliferation (AiP) which is a phenomenon characterized by the release of mitogens such as hedgehog (Hh) and wingless following stress stimulus to promote the proliferation of adjacent cells to restore organ integrity and function $[22,124,125]$. In mice, the splice Mp53Y isoform is upregulated in stem cells in a tissue-specific manner following a damaging event. In liver tissue, CCL4-induced lesions regress

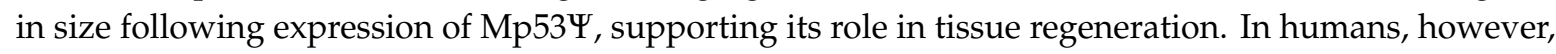
endogenous Mp534 has only been characterized in the HOP62 cancer cell line which possesses a mutation in the acceptor splice site of TP53 intron 6 [32]. This, therefore, associates TP53 splice site mutations with oncogenic functions. Taken together, much of the evidence on p53 isoform role in tissue regenerations is convincing albeit limited to animal models.

\section{Detecting p53 Isoforms}

RT-qPCR has been the most widely used and reliable technique to investigate p53 isoform expression. Alternatively, the approach to detect p53 isoform expression at the transcriptome level via analysis of RNA-sequence data from large cancer repositories such as The Cancer Genome Atlas (TCGA) proves challenging with the available bioinformatic platforms (RSEM method) having poor sensitivity for detecting low abundance splice variants [126]. The challenge with deriving conclusions based on the level of p53 mRNA variants is that their expression levels do not always correlate with the protein expression level of the corresponding isoforms [22]. Several antibodies have been developed to investigate 533 isoform expression at the protein level using Western blotting, immunohistochemistry (IHC) or immunofluorescence [22]. The use of IHC remains a common technique to investigate TP53 mutational status in routine pathology [127]. Therefore, given the significance of p53 isoforms in multiple biological processes, it would be a logical endeavour to investigate p53 isoform expression and their spatiotemporal distribution in normal, precancerous and cancer tissues by IHC. Several groups have attempted to identify p53 isoforms with IHC with varying degrees of success [92,102,128]. Significant limitations experienced include the paucity of p53 isoform-specific antibodies and weak signal intensity. The latter is an expected challenge in attempting to visualize p53 isoforms, including p53 $\alpha$, via IHC as they are not as abundantly expressed as structural proteins such as actin, vimentin and cytokeratin. Additionally, as p53 $\alpha$ is notorious for extensive PTMs, one would expect p53 isoforms to also be similarly modified, thus potentially affecting the target epitope of the isoform-specific antibodies. Other methods to study isoform expression in situ include RNAscope in situ hybridisation which has been employed to study $\Delta 133$ p $53 \beta$ expression in formalin-fixed paraffin-embedded glioblastoma tissue [102]. Targeted proteomics with liquid chromatography-tandem mass spectrometry (LC-MS/MS) is emerging as a reliable method to quantify p53 isoform expression at the protein level. For example, Jiang et al. combined molecularly imprinted polymers and LC-MS/MS to reliably quantify C-terminus p53 isoform variants in several breast cancer cell lines [129].

\section{Concluding Remarks}

Based on the accumulated evidence, it is gradually becoming evident that the dysregulation of p53 isoform balance is biologically relevant not only in the pathogenesis of cancer but also in neurodegenerative, inflammatory, infection and progeria associated diseases. Investigating p53 isoforms offers a new vantage point to analyse and unravel the multiple biological functions of p53, which have been elusive to therapeutic targeting in the last few decades. Numerous questions remain; hence, a rigorous, concerted effort is essential to (1) develop more p53 isoform-specific antibodies with appreciation of PTMs; (2) interrogate the mechanism underpinning the shift in isoform balance in response to a particular cell context or stimulus; and (3) design clinical studies which investigate the co-expression of $\mathrm{p} 53$ isoforms with outcomes. These are key steps towards deciphering the role of p53 
isoforms in both pathology and physiology and determine how clinicians can manipulate the isoforms' activities to rationally trigger the appropriate tumour response on patient clinical outcomes.

Funding: This work was supported by an Intercalated Degree Grant by the British Association of Dermatologists (TA). JC Bourdon is a fellow of Breast Cancer Now (2012MaySF127).

Conflicts of Interest: The authors declare no conflict of interest.

\section{Abbreviations}

$\begin{array}{ll}\text { IRES } & \text { Internal ribosome entry site } \\ \text { TAD } & \text { Transactivation domain } \\ \text { IDR } & \text { Intrinsic disorder region } \\ \text { DBD } & \text { DNA-binding domain } \\ \text { PTM } & \text { Post-translational modifications } \\ \text { HGPS } & \text { Hutchinson-Gilford Progeria Syndrome } \\ \text { SASP } & \text { Senescence associated secretory phenotype } \\ \text { AIP } & \text { Apoptosis-induced proliferation } \\ \text { Hh } & \text { Hedgehog } \\ \text { IHC } & \text { Immunohistochemistry } \\ \text { PRD } & \text { Proline-rich domain } \\ \text { HD } & \text { Hinge domain } \\ \text { LFS } & \text { Li Fraumeni Syndrome } \\ \text { AML } & \text { Acute myeloid leukaemia } \\ \text { PARP } & \text { Poly-ADP ribose polymerase }\end{array}$

\section{References}

1. Lane, D.P. Cancer. p53, guardian of the genome. Nature 1992, 358, 15-16. [CrossRef] [PubMed]

2. Kastenhuber, E.R.; Lowe, S.W. Putting p53 in Context. Cell 2017, 170, 1062-1078. [CrossRef] [PubMed]

3. Vousden, K.H.; Lane, D.P. p53 in health and disease. Nat. Rev. Mol. Cell Biol. 2007, 8, 275-283. [CrossRef] [PubMed]

4. Olivos, D.J.; Mayo, L.D. Emerging non-canonical functions and regulation by p53: p53 and stemness. Int. J. Mol. Sci. 2016, 17, 1982. [CrossRef]

5. Berkers, C.R.; Maddocks, O.D.K.; Cheung, E.C.; Mor, I.; Vousden, K.H. Metabolic regulation by p53 family members. Cell Metab. 2013, 18, 617-633. [CrossRef]

6. Jiang, L.; Kon, N.; Li, T.; Wang, S.-J.; Su, T.; Hibshoosh, H.; Baer, R.; Gu, W. Ferroptosis as a p53-mediated activity during tumour suppression. Nature 2015, 520, 57-62. [CrossRef]

7. Allen, M.A.; Andrysik, Z.; Dengler, V.L.; Mellert, H.S.; Guarnieri, A.; Freeman, J.A.; Sullivan, K.D.; Galbraith, M.D.; Luo, X.; Kraus, W.L.; et al. Global analysis of p53-regulated transcription identifies its direct targets and unexpected regulatory mechanisms. Elife 2014, 3, e02200. [CrossRef]

8. Simbulan-Rosenthal, C.M.; Rosenthal, D.S.; Luo, R.B.; Samara, R.; Jung, M.; Dritschilo, A.; Spoonde, A.; Smulson, M.E. Poly(ADP-ribosyl) ation of p53 in vitro and in vivo modulates binding to its DNA consensus sequence. Neoplasia 2001, 3, 179-188. [CrossRef]

9. Aylon, Y.; Oren, M. The Paradox of p53: What, How, and Why? Cold Spring Harb. Perspect. Med. 2016, 6, a026328. [CrossRef]

10. Hart, Y.; Alon, U. The utility of paradoxical components in biological circuits. Mol. Cell 2013, 49, $213-221$. [CrossRef]

11. Kandoth, C.; McLellan, M.D.; Vandin, F.; Ye, K.; Niu, B.; Lu, C.; Xie, M.; Zhang, Q.; McMichael, J.F.; Wyczalkowski, M.A.; et al. Mutational landscape and significance across 12 major cancer types. Nature 2013, 502, 333-339. [CrossRef] [PubMed]

12. Muller, P.A.J.; Vousden, K.H. p53 mutations in cancer. Nat. Cell Biol. 2013, 15, 2-8. [CrossRef] [PubMed]

13. Hollstein, M.; Sidransky, D.; Vogelstein, B.; Harris, C.C. p53 mutations in human cancers. Science 1991, 253, 49-53. [CrossRef] [PubMed] 
14. Rivlin, N.; Brosh, R.; Oren, M.; Rotter, V. Mutations in the p53 Tumor Suppressor Gene: Important Milestones at the Various Steps of Tumorigenesis. Genes Cancer 2011, 2, 466-474. [CrossRef] [PubMed]

15. Baker, S.J.; Fearon, E.R.; Nigro, J.M.; Hamilton, S.R.; Preisinger, A.C.; Jessup, J.M.; Vantuinen, P.; Ledbetter, D.H.; Barker, D.F.; Nakamura, Y.; et al. Chromosome 17 deletions and p53 gene mutations in colorectal carcinomas. Science 1989, 244, 217-221. [CrossRef]

16. Bourdon, J.-C.; Fernandes, K.; Murray-Zmijewski, F.; Liu, G.; Diot, A.; Xirodimas, D.P.; Saville, M.K.; Lane, D.P. p53 isoforms can regulate p53 transcriptional activity. Genes Dev. 2005, 19, 2122-2137. [CrossRef]

17. Zydowicz-Machtel, P.; Swiatkowska, A.; Popenda, E.; Gorska, A.; Ciesiołka, J. Variants of the $5^{\prime}$-terminal region of p53 mRNA influence the ribosomal scanning and translation efficiency. Sci. Rep. 2018, 8, 1533. [CrossRef]

18. Lane, D.P.; Cheok, C.F.; Brown, C.; Madhumalar, A.; Ghadessy, F.J.; Verma, C. Mdm2 and p53 are highly conserved from placozoans to man. Cell Cycle 2010, 9, 540-547. [CrossRef]

19. Matlashewski, G.; Lamb, P.; Pim, D.; Peacock, J.; Crawford, L.; Benchimol, S. Isolation and characterization of a human p53 cDNA clone: Expression of the human p53 gene. EMBO J. 1984, 3, 3257-3262. [CrossRef]

20. Wolf, D.; Harris, N.; Goldfinger, N.; Rotter, V. Isolation of a full-length mouse cDNA clone coding for an immunologically distinct p53 molecule. Mol. Cell. Biol. 1985, 5, 127-132. [CrossRef]

21. Courtois, S.; Verhaegh, G.; North, S.; Luciani, M.G.; Lassus, P.; Hibner, U.; Oren, M.; Hainaut, P. $\Delta$ N-p53, a natural isoform of p53 lacking the first transactivation domain, counteracts growth suppression by wild-type p53. Oncogene 2002, 21, 6722-6728. [CrossRef] [PubMed]

22. Joruiz, S.M.; Bourdon, J.C. P53 isoforms: Key regulators of the cell fate decision. Cold Spring Harb. Perspect. Med. 2016, 6, a026039. [CrossRef] [PubMed]

23. Marcel, V.; Perrier, S.; Aoubala, M.; Ageorges, S.; Groves, M.J.; Diot, A.; Fernandes, K.; Tauro, S.; Bourdon, J.-C. $\Delta 160$ p53 is a novel N-terminal p53 isoform encoded by $\Delta 133$ p53 transcript. FEBS Lett. 2010, 584, 4463-4468. [CrossRef] [PubMed]

24. Yin, Y.; Stephen, C.W.; Luciani, M.G.; Fåhraeus, R. p53 stability and activity is regulated by Mdm2-mediated induction of alternative p53 translation products. Nat. Cell Biol. 2002, 4, 462-467. [CrossRef] [PubMed]

25. Grover, R.; Ray, P.S.; Das, S. Polypyrimidine tract binding protein regulates IRES-mediated translation of p53 isoforms. Cell Cycle 2008, 7, 2189-2198. [CrossRef] [PubMed]

26. Sharathchandra, A.; Katoch, A.; Das, S. IRES mediated translational regulation of p53 isoforms. Wiley Interdiscip. Rev. RNA 2014, 5, 131-139. [CrossRef]

27. Marcel, V.; Dichtel-Danjoy, M.-L.; Sagne, C.; Hafsi, H.; Ma, D.; Ortiz-Cuaran, S.; Olivier, M.; Hall, J.; Mollereau, B.; Hainaut, P.; et al. Biological functions of p53 isoforms through evolution: Lessons from animal and cellular models. Cell Death Differ. 2011, 18, 1815-1824. [CrossRef]

28. Jin, S.; Martinek, S.; Joo, W.S.; Wortman, J.R.; Mirkovic, N.; Sali, A.; Yandell, M.D.; Pavletich, N.P.; Young, M.W.; Levine, A.J. Identification and characterization of a p53 homologue in Drosophila melanogaster. Proc. Natl. Acad. Sci. USA 2000, 97, 7301-7306. [CrossRef]

29. Marcel, V.; Vijayakumar, V.; Fernández-Cuesta, L.; Hafsi, H.; Sagne, C.; Hautefeuille, A.; Olivier, M.; Hainaut, P. $\mathrm{P} 53$ regulates the transcription of its $\Delta 133$ p53 isoform through specific response elements contained within the TP53 P2 internal promoter. Oncogene 2010, 29, 2691-2700. [CrossRef]

30. Davidson, W.R.; Kari, C.; Ren, Q.; Daroczi, B.; Dicker, A.P.; Rodeck, U. Differential regulation of p53 function by the N-terminal Np53 and 113p53 isoforms in zebrafish embryos. BMC Dev. Biol. 2010, 10, 102. [CrossRef]

31. Kazantseva, M.; Mehta, S.; Eiholzer, R.A.; Hung, N.; Wiles, A.; Slatter, T.L.; Braithwaite, A.W. A mouse model of the $\Delta 133$ p53 isoform: Roles in cancer progression and inflammation. Mamm. Genome 2018, 29, 839-842. [CrossRef] [PubMed]

32. Senturk, S.; Yao, Z.; Camiolo, M.; Stiles, B.; Rathod, T.; Walsh, A.M.; Nemajerova, A.; Lazzara, M.J.; Altorki, N.K.; Krainer, A.; et al. p53世 is a transcriptionally inactive p53 isoform able to reprogram cells toward a metastatic-like state. Proc. Natl. Acad. Sci. USA 2014, 111, 3287-3296. [CrossRef] [PubMed]

33. Fischer, M. Census and evaluation of p53 target genes. Oncogene 2017, 36, 3943-3956. [CrossRef] [PubMed]

34. Stenger, J.E.; Tegtmeyer, P.; Mayr, G.A.; Reed, M.; Wang, Y.; Wang, P.; Hough, P.V.; Mastrangelo, I.A. p53 oligomerization and DNA looping are linked with transcriptional activation. EMBO J. 1994, 13, 6011-6020. [CrossRef]

35. Dunker, A.K.; Obradovic, Z.; Romero, P.; Garner, E.C.; Brown, C.J. Intrinsic protein disorder in complete genomes. Genome Inform. 2000, 11, 161-171. 
36. Wright, P.E.; Dyson, H.J. Intrinsically disordered proteins in cellular signalling and regulation. Nat. Rev. Mol. Cell Biol. 2015, 16, 18-29. [CrossRef]

37. Raj, N.; Attardi, L.D. The Transactivation Domains of the p53 Protein. Cold Spring Harb. Perspect. Med. 2017, 7, a026047. [CrossRef]

38. Sullivan, K.D.; Galbraith, M.D.; Andrysik, Z.; Espinosa, J.M. Mechanisms of transcriptional regulation by p53. Cell Death Differ. 2018, 25, 133-143. [CrossRef]

39. Opitz, R.; Müller, M.; Reuter, C.; Barone, M.; Soicke, A.; Roske, Y.; Piotukh, K.; Huy, P.; Beerbaum, M.; Wiesner, B.; et al. A modular toolkit to inhibit proline-rich motif-mediated protein-protein interactions. Proc. Natl. Acad. Sci. USA 2015, 112, 5011-5016. [CrossRef]

40. Toledo, F.; Krummel, K.A.; Lee, C.J.; Liu, C.W.; Rodewald, L.W.; Tang, M.; Wahl, G.M. A mouse p53 mutant lacking the proline-rich domain rescues Mdm4 deficiency and provides insight into the Mdm2-Mdm4-p53 regulatory network. Cancer Cell 2006, 9, 273-285. [CrossRef]

41. Baptiste, N.; Friedlander, P.; Chen, X.; Prives, C. The proline-rich domain of p53 is required for cooperation with anti-neoplastic agents to promote apoptosis of tumor cells. Oncogene 2002, 21, 9-21. [CrossRef] [PubMed]

42. Joerger, A.C.; Fersht, A.R. The tumor suppressor p53: From structures to drug discovery. Cold Spring Harb. Perspect. Biol. 2010, 2, a000919. [CrossRef] [PubMed]

43. Pavletich, N.P.; Chambers, K.A.; Pabo, C.O. The DNA-binding domain of p53 contains the four conserved regions and the major mutation hot spots. Genes Dev. 1993, 7, 2556-2564. [CrossRef] [PubMed]

44. Xue, Y.; Wang, S.; Feng, X. Influence of magnesium ion on the binding of p53 DNA-binding domain to DNA-response elements. J. Biochem. 2009, 146, 77-85. [CrossRef]

45. Natan, E.; Baloglu, C.; Pagel, K.; Freund, S.M.V.; Morgner, N.; Robinson, C.V.; Fersht, A.R.; Joerger, A.C. Interaction of the p53 DNA-Binding Domain with Its N-Terminal Extension Modulates the Stability of the p53 Tetramer. J. Mol. Biol. 2011, 409, 358-368. [CrossRef]

46. Bouaoun, L.; Sonkin, D.; Ardin, M.; Hollstein, M.; Byrnes, G.; Zavadil, J.; Olivier, M. TP53 Variations in Human Cancers: New Lessons from the IARC TP53 Database and Genomics Data. Hum. Mutat. 2016, 37, 865-876. [CrossRef]

47. Lei, J.; Qi, R.; Tang, Y.; Wang, W.; Wei, G.; Nussinov, R.; Ma, B. Conformational stability and dynamics of the cancer-associated isoform $\triangle 133 \mathrm{p} 53 \beta$ are modulated by $\mathrm{p} 53$ peptides and p53-specific DNA. FASEB J. 2019, 33, 4225-4235. [CrossRef]

48. Aurelio, O.N.; Cajot, J.F.; Hua, M.L.H.; Khwaja, Z.; Stanbridge, E.J. Germ-line-derived hinge domain p53 mutants have lost apoptotic but not cell cycle arrest functions. Cancer Res. 1998, 58, 2190-2195.

49. Scoumanne, A.; Harms, K.L.; Chen, X. Structural basis for gene activation by p53 family members. Cancer Biol. Ther. 2005, 4, 1178-1185. [CrossRef]

50. Kong, X.T.; Gao, H.; Stanbridge, E.J. Mechanisms of Differential Activation of Target Gene Promoters by p53 Hinge Domain Mutants with Impaired Apoptotic Function. J. Biol. Chem. 2001, 276, 32990-33000. [CrossRef]

51. Mateu, M.G.; Fersht, A.R. Nine hydrophobic side chains are key determinants of the thermodynamic stability and oligomerization status of tumour suppressor p53 tetramerization domain. EMBO J. 1998, 17, 2748-2758. [CrossRef] [PubMed]

52. Beckerman, R.; Yoh, K.; Mattia-Sansobrino, M.; Zupnick, A.; Laptenko, O.; Karni-Schmidt, O.; Ahn, J.; Byeon, I.-J.; Keezer, S.; Prives, C. Lysines in the tetramerization domain of p53 selectively modulate G1 arrest. Cell Cycle 2016, 15, 1425-1438. [CrossRef] [PubMed]

53. Sauer, M.; Bretz, A.C.; Beinoraviciute-Kellner, R.; Beitzinger, M.; Burek, C.; Rosenwald, A.; Harms, G.S.; Stiewe, T. C-terminal diversity within the p53 family accounts for differences in DNA binding and transcriptional activity. Nucleic Acids Res. 2008, 36, 1900-1912. [CrossRef] [PubMed]

54. McKinney, K.; Mattia, M.; Gottifredi, V.; Prives, C. p53 Linear Diffusion along DNA Requires Its C Terminus. Mol. Cell 2004, 16, 413-424. [CrossRef] [PubMed]

55. Meek, D.W.; Anderson, C.W. Posttranslational modification of p53: Cooperative integrators of function. Cold Spring Harb. Perspect. Biol. 2009, 1, a000950. [CrossRef] [PubMed]

56. Fujita, K.; Mondal, A.M.; Horikawa, I.; Nguyen, G.H.; Kumamoto, K.; Sohn, J.J.; Bowman, E.D.; Mathe, E.A.; Schetter, A.J.; Pine, S.R.; et al. p53 isoforms $\Delta 133$ p53 and p53 $\beta$ are endogenous regulators of replicative cellular senescence. Nat. Cell Biol. 2009, 11, 1135-1142. [CrossRef] 
57. Mondal, A.M.; Horikawa, I.; Pine, S.R.; Fujita, K.; Morgan, K.M.; Vera, E.; Mazur, S.J.; Appella, E.; Vojtesek, B.; Blasco, M.A.; et al. p53 isoforms regulate aging- and tumor-associated replicative senescence in T lymphocytes. J. Clin. Investig. 2013, 123, 5247-5257. [CrossRef]

58. Von Muhlinen, N.; Horikawa, I.; Alam, F.; Isogaya, K.; Lissa, D.; Vojtesek, B.; Lane, D.P.; Harris, C.C. p53 isoforms regulate premature aging in human cells. Oncogene 2018, 37, 2379-2393. [CrossRef]

59. Maier, B.; Gluba, W.; Bernier, B.; Turner, T.; Mohammad, K.; Guise, T.; Sutherland, A.; Thorner, M.; Scrable, H. Modulation of mammalian life span by the short isoform of p53. Genes Dev. 2004, 18, 306-319. [CrossRef]

60. Gambino, V.; De Michele, G.; Venezia, O.; Migliaccio, P.; Dall'Olio, V.; Bernard, L.; Minardi, S.P.; Fazia, M.A.D.; Bartoli, D.; Servillo, G.; et al. Oxidative stress activates a specific p53 transcriptional response that regulates cellular senescence and aging. Aging Cell 2013, 12, 435-445. [CrossRef]

61. Slatter, T.L.; Hung, N.; Campbell, H.; Rubio, C.; Mehta, R.; Renshaw, P.; Williams, G.; Wilson, M.; Engelmann, A.; Jeffs, A.; et al. Hyperproliferation, cancer, and inflammation in mice expressing a $\Delta 133$ p53-like isoform. Blood 2011, 117, 5166-5177. [CrossRef] [PubMed]

62. Xie, N.; Chen, M.; Dai, R.; Zhang, Y.; Zhao, H.; Song, Z.; Zhang, L.; Li, Z.; Feng, Y.; Gao, H.; et al. SRSF1 promotes vascular smooth muscle cell proliferation through a $\Delta 133$ p53/EGR1/KLF5 pathway. Nat. Commun. 2017, 8, 16016. [CrossRef] [PubMed]

63. Mondal, A.M.; Zhou, H.; Horikawa, I.; Suprynowicz, F.A.; Li, G.; Dakic, A.; Rosenthal, B.; Ye, L.; Harris, C.C.; Schlegel, R.; et al. $\Delta 133$ p53 $\alpha$, a natural p53 isoform, contributes to conditional reprogramming and long-term proliferation of primary epithelial cells. Cell Death Dis. 2018, 9, 750. [CrossRef] [PubMed]

64. Ungewitter, E.; Scrable, H. Delta40p53 controls the switch from pluripotency to differentiation by regulating IGF signaling in ESCs. Genes Dev. 2010, 24, 2408-2419. [CrossRef]

65. Marcel, V.; Fernandes, K.; Terrier, O.; Lane, D.P.; Bourdon, J.-C. Modulation of p53 $\beta$ and p53 $\gamma$ expression by regulating the alternative splicing of TP53 gene modifies cellular response. Cell Death Differ. 2014, 21, 1377-1387. [CrossRef]

66. Takahashi, R.; Markovic, S.N.; Scrable, H.J. Dominant Effects of $\Delta 40$ p53 on p53 Function and Melanoma Cell Fate. J. Investig. Dermatol. 2014, 134, 791-800. [CrossRef]

67. Ou, Z.; Yin, L.; Chang, C.; Peng, J.; Chen, J. Protein Interaction Between p53 and $\Delta 113$ p53 Is Required for the Anti-Apoptotic Function of $\Delta 113$ p53. J. Genet. Genom. 2014, 41, 53-62. [CrossRef]

68. Chen, J.; Ng, S.M.; Chang, Q.; Zhang, Z.; Bourdon, J.C.; Lane, D.P.; Peng, J. P53 isoform $\Delta 113$ p53 is a p53 target gene that antagonizes p53 apoptotic activity via BclxL activation in zebrafish. Genes Dev. 2009, 23, 278-290. [CrossRef]

69. Arsic, N.; Ho-Pun-Cheung, A.; Evelyne, C.; Assenat, E.; Jarlier, M.; Anguille, C.; Colard, M.; Pezet, M.; Roux, P.; Gadea, G. The p53 isoform delta133p53ß regulates cancer cell apoptosis in a RhoB-dependent manner. PLoS ONE 2017, 12, e0172125. [CrossRef]

70. Sawhney, S.; Hood, K.; Shaw, A.; Braithwaite, A.W.; Stubbs, R.; Hung, N.A.; Royds, J.A.; Slatter, T.L. Alpha-Enolase Is Upregulated on the Cell Surface and Responds to Plasminogen Activation in Mice Expressing a $\Delta 133$ p53 $\alpha$ Mimic. PLoS ONE 2015, 10, e0116270. [CrossRef]

71. Gong, L.; Gong, H.; Pan, X.; Chang, C.; Ou, Z.; Ye, S.; Yin, L.; Yang, L.; Tao, T.; Zhang, Z.; et al. p53 isoform $\Delta 113$ p53/ $\triangle 133$ p53 promotes DNA double-strand break repair to protect cell from death and senescence in response to DNA damage. Cell Res. 2015, 25, 351-369. [CrossRef] [PubMed]

72. Gong, H.; Zhang, Y.; Jiang, K.; Ye, S.; Chen, S.; Zhang, Q.; Peng, J.; Chen, J. p73 coordinates with $\Delta 133$ p53 to promote DNA double-strand break repair. Cell Death Differ. 2018, 25, 1063-1079. [CrossRef] [PubMed]

73. Slatter, T.L.; Hung, N.; Bowie, S.; Campbell, H.; Rubio, C.; Speidel, D.; Wilson, M.; Baird, M.; Royds, J.A.; Braithwaite, A.W. $\Delta 122$ p53, a mouse model of $\Delta 133 p 53 \alpha$, enhances the tumor-suppressor activities of an attenuated p53 mutant. Cell Death Dis. 2015, 6, e1783. [CrossRef] [PubMed]

74. Zang, Y.; Shi, Y.; Liu, K.; Qiao, L.; Guo, X.; Chen, D. $\Delta 40$ p53 is involved in the inactivation of autophagy and contributes to inhibition of cell death in HCT116- $\Delta 40$ p53 cells. Oncotarget 2017, 8, 12754-12763. [CrossRef]

75. Arsic, N.; Gadea, G.; Lagerqvist, E.L.; Bußon, M.; Cahuzac, N.; Brock, C.; Hollande, F.; Gire, V.; Pannequin, J.; Roux, P. The p53 isoform $\Delta 133$ p53 $\beta$ promotes cancer stem cell potential. Stem Cell Rep. 2015, 4, 531-540. [CrossRef]

76. Gadea, G.; Arsic, N.; Fernandes, K.; Diot, A.; Joruiz, S.M.; Abdallah, S.; Meuray, V.; Vinot, S.; Anguille, C.; Remenyi, J.; et al. TP53 drives invasion through expression of its $\Delta 133$ p53 $\beta$ variant. Elife 2016, 5, e14734. [CrossRef] 
77. Campbell, H.; Fleming, N.; Roth, I.; Mehta, S.; Wiles, A.; Williams, G.; Vennin, C.; Arsic, N.; Parkin, A.; Pajic, M.; et al. $\Delta 133$ p53 isoform promotes tumour invasion and metastasis via interleukin-6 activation of JAK-STAT and RhoA-ROCK signaling. Nat. Commun. 2018, 9, 254. [CrossRef]

78. Liu, P.K.; Kraus, E.; Wu, T.A.; Strong, L.C.; Tainsky, M.A. Analysis of genomic instability in Li-Fraumeni fibroblasts with germline p53 mutations. Oncogene 1996, 12, 2267-2278.

79. Khoury, M.P.; Bourdon, J.C. P53 isoforms: An intracellular microprocessor? Genes Cancer 2011, 2, $453-465$. [CrossRef]

80. Hafsi, H.; Santos-Silva, D.; Courtois-Cox, S.; Hainaut, P. Effects of $\Delta 40$ p53, an isoform of p53 lacking the $\mathrm{N}$-terminus, on transactivation capacity of the tumor suppressor protein p53. BMC Cancer 2013, 13, 134. [CrossRef]

81. Aoubala, M.; Murray-Zmijewski, F.; Khoury, M.P.; Fernandes, K.; Perrier, S.; Bernard, H.; Prats, A.-C.; Lane, D.P.; Bourdon, J.-C. p53 directly transactivates $\Delta 133 \mathrm{p} 53 \alpha$, regulating cell fate outcome in response to DNA damage. Cell Death Differ. 2011, 18, 248-258. [CrossRef] [PubMed]

82. Solomon, H.; Bräuning, B.; Fainer, I.; Ben-Nissan, G.; Rabani, S.; Goldfinger, N.; Moscovitz, O.; Shakked, Z.; Rotter, V.; Sharon, M. Post-translational regulation of p53 function through $20 S$ proteasome-mediated cleavage. Cell Death Differ. 2017, 24, 2187-2198. [CrossRef] [PubMed]

83. Nie, L.; Sasaki, M.; Maki, C.G. Regulation of p53 Nuclear Export through Sequential Changes in Conformation and Ubiquitination. J. Biol. Chem. 2007, 282, 14616-14625. [CrossRef] [PubMed]

84. Pehar, M.; Ko, M.H.; Li, M.; Scrable, H.; Puglielli, L. P44, the "longevity-assurance" isoform of P53, regulates tau phosphorylation and is activated in an age-dependent fashion. Aging Cell 2014, 13, 449-456. [CrossRef]

85. Camus, S.; Ménendez, S.; Fernandes, K.; Kua, N.; Liu, G.; Xirodimas, D.P.; Lane, D.P.; Bourdon, J.-C. The p53 isoforms are differentially modified by Mdm2. Cell Cycle 2012, 11, 1646-1655. [CrossRef]

86. Oren, M.; Rotter, V. Mutant p53 Gain-of-Function in Cancer. Cold Spring Harb. Perspect. Biol. 2010, 2, a001107. [CrossRef]

87. Candeias, M.M.; Hagiwara, M.; Matsuda, M. Cancer-specific mutations in p53 induce the translation of $\triangle 160$ p53 promoting tumorigenesis. EMBO Rep. 2016, 17, 1542-1551. [CrossRef]

88. Espíndola, S.L.; Damianich, A.; Alvarez, R.J.; Sartor, M.; Belforte, J.E.; Ferrario, J.E.; Gallo, J.M.; Avale, M.E. Modulation of Tau Isoforms Imbalance Precludes Tau Pathology and Cognitive Decline in a Mouse Model of Tauopathy. Cell Rep. 2018, 23, 709-715. [CrossRef]

89. Boldrup, L.; Bourdon, J.-C.; Coates, P.J.; Sjöström, B.; Nylander, K. Expression of p53 isoforms in squamous cell carcinoma of the head and neck. Eur. J. Cancer 2007, 43, 617-623. [CrossRef]

90. Fragou, A.; Tzimagiorgis, G.; Karageorgopoulos, C.; Barbetakis, N.; Lazopoulos, A.; Papaioannou, M.; Haitoglou, C.; Kouidou, S. Increased $\Delta 133$ p53 mRNA in lung carcinoma corresponds with reduction of p21 expression. Mol. Med. Rep. 2017, 15, 1455-1460. [CrossRef]

91. Moore, H.C.; Jordan, L.B.; Bray, S.E.; Baker, L.; Quinlan, P.R.; Purdie, C.A.; Thompson, A.M.; Bourdon, J.-C.; Fuller-Pace, F.V. The RNA helicase p68 modulates expression and function of the $\Delta 133$ isoform(s) of p53, and is inversely associated with $\Delta 133$ p53 expression in breast cancer. Oncogene 2010, 29, 6475-6484. [CrossRef] [PubMed]

92. Milićević, Z.; Bajić, V.; Živković, L.; Kasapović, J.; Andjelković, U.; Spremo-Potparević, B. Identification of p53 and its isoforms in human breast carcinoma cells. Sci. World J. 2014, 2014, 618698. [CrossRef] [PubMed]

93. Avery-Kiejda, K.A.; Morten, B.; Wong-Brown, M.W.; Mathe, A.; Scott, R.J. The relative mRNA expression of p53 isoforms in breast cancer is associated with clinical features and outcome. Carcinogenesis 2014, 35, 586-596. [CrossRef] [PubMed]

94. Bourdon, J.-C.; Khoury, M.P.; Diot, A.; Baker, L.; Fernandes, K.; Aoubala, M.; Quinlan, P.; Purdie, C.A.; Jordan, L.B.; Prats, A.-C.; et al. p53 mutant breast cancer patients expressing p53 $\gamma$ have as good a prognosis as wild-type p53 breast cancer patients. Breast Cancer Res. 2011, 13, R7. [CrossRef] [PubMed]

95. Morten, B.C.; Scott, R.J.; Avery-Kiejda, K.A. Comparison of the QuantiGene 2.0 Assay and Real-Time RT-PCR in the Detection of p53 Isoform mRNA Expression in Formalin-Fixed Paraffin-Embedded Tissues-A Preliminary Study. PLoS ONE 2016, 11, e0165930. [CrossRef]

96. Marabese, M.; Marchini, S.; Marrazzo, E.; Mariani, P.; Cattaneo, D.; Fossati, R.; Compagnoni, A.; Signorelli, M.; Moll, U.M.; Codegoni, A.M.; et al. Expression levels of p53 and p73 isoforms in stage I and stage III ovarian cancer. Eur. J. Cancer 2008, 44, 131-141. [CrossRef] 
97. Hofstetter, G.; Berger, A.; Berger, R.; Zorić, A.; Braicu, E.I.; Reimer, D.; Fiegl, H.; Marth, C.; Zeimet, A.G.; Ulmer, H.; et al. The N-Terminally Truncated p53 Isoform $\triangle 40$ p53 Influences Prognosis in Mucinous Ovarian Cancer. Int. J. Gynecol. Cancer 2012, 22, 372-379. [CrossRef]

98. Hofstetter, G.; Berger, A.; Schuster, E.; Wolf, A.; Hager, G.; Vergote, I.; Cadron, I.; Sehouli, J.; Braicu, E.I.; Mahner, S.; et al. $\Delta 133$ p53 is an independent prognostic marker in p53 mutant advanced serous ovarian cancer. Br. J. Cancer 2011, 105, 1593-1599. [CrossRef]

99. Bischof, K.; Knappskog, S.; Hjelle, S.M.; Stefansson, I.; Woie, K.; Salvesen, H.B.; Gjertsen, B.T.; Bjorge, L. Influence of p53 Isoform Expression on Survival in High-Grade Serous Ovarian Cancers. Sci. Rep. 2019, 9, 5244. [CrossRef]

100. Nutthasirikul, N.; Limpaiboon, T.; Leelayuwat, C.; Patrakitkomjorn, S.; Jearanaikoon, P. Ratio disruption of the $\Delta 133$ p53 and TAp53 isoform equilibrium correlates with poor clinical outcome in intrahepatic cholangiocarcinoma. Int. J. Oncol. 2013, 42, 1181-1188. [CrossRef]

101. Takahashi, R.; Giannini, C.; Sarkaria, J.N.; Schroeder, M.; Rogers, J.; Mastroeni, D.; Scrable, H. p53 isoform profiling in glioblastoma and injured brain. Oncogene 2013, 32, 3165-3174. [CrossRef] [PubMed]

102. Kazantseva, M.; Eiholzer, R.A.; Mehta, S.; Taha, A.; Bowie, S.; Roth, I.; Zhou, J.; Joruiz, S.M.; Royds, J.A.; Hung, N.A.; et al. Elevation of the TP53 isoform $\triangle 133$ p53 $\beta$ in glioblastomas: An alternative to mutant p53 in promoting tumor development. J. Pathol. 2018, 246, 77-88. [CrossRef] [PubMed]

103. Song, W.; Huo, S.W.; Lü, J.J.; Liu, Z.; Fang, X.L.; Jin, X.B.; Yuan, M.Z. Expression of p53 isoforms in renal cell carcinoma. Chin. Med. J. 2009, 122, 921-926. [PubMed]

104. Zhang, H.; Zhao, Y.; Sun, P.; Zhao, M.; Su, Z.; Jin, X.; Song, W. p53ß: A new prognostic marker for patients with clear-cell renal cell carcinoma from 5.3 years of median follow-up. Carcinogenesis 2018, 39, 369-374. [CrossRef] [PubMed]

105. Knezović Florijan, M.; Ozretić, P.; Bujak, M.; Pezzè, L.; Ciribilli, Y.; Kaštelan, Ž.; Slade, N.; Hudolin, T. The role of p53 isoforms' expression and p53 mutation status in renal cell cancer prognosis. Urol. Oncol. Semin. Orig. Investig. 2019, 37, 578. [CrossRef]

106. Bischof, K.; Knappskog, S.; Stefansson, I.; McCormack, E.M.; Trovik, J.; Werner, H.M.J.; Woie, K.; Gjertsen, B.T.; Bjorge, L. High expression of the p53 isoform $\gamma$ is associated with reduced progression-free survival in uterine serous carcinoma. BMC Cancer 2018, 18, 684. [CrossRef]

107. Ånensen, N.; Hjelle, S.M.; Van Belle, W.; Haaland, I.; Silden, E.; Bourdon, J.-C.; Hovland, R.; Taskén, K.; Knappskog, S.; Lønning, P.E.; et al. Correlation analysis of p53 protein isoforms with NPM1/FLT3 mutations and therapy response in acute myeloid leukemia. Oncogene 2012, 31, 1533-1545. [CrossRef]

108. Ozretić, P.; Hanžić, N.; Proust, B.; Sabol, M.; Trnski, D.; Radić, M.; Musani, V.; Ciribilli, Y.; Milas, I.; Puljiz, Z.; et al. Expression profiles of p53/p73, NME and GLI families in metastatic melanoma tissue and cell lines. Sci. Rep. 2019, 9, 1-13. [CrossRef]

109. Leroy, B.; Ballinger, M.L.; Baran-Marszak, F.; Bond, G.L.; Braithwaite, A.; Concin, N.; Donehower, L.A.; El-Deiry, W.S.; Fenaux, P.; Gaidano, G.; et al. Recommended Guidelines for Validation, Quality Control, and Reporting of TP53 Variants in Clinical Practice. Cancer Res. 2017, 77, 1250-1260. [CrossRef]

110. Surget, S.; Khoury, M.P.; Bourdon, J.C. Uncovering the role of p53 splice variants in human malignancy: A clinical perspective. Onco Targets Ther. 2013, 7, 57-67.

111. Giacomelli, A.O.; Yang, X.; Lintner, R.E.; McFarland, J.M.; Duby, M.; Kim, J.; Howard, T.P.; Takeda, D.Y.; Ly, S.H.; Kim, E.; et al. Mutational processes shape the landscape of TP53 mutations in human cancer. Nat. Genet. 2018, 50, 1381-1387. [CrossRef] [PubMed]

112. Kotler, E.; Shani, O.; Goldfeld, G.; Lotan-Pompan, M.; Tarcic, O.; Gershoni, A.; Hopf, T.A.; Marks, D.S.; Oren, M.; Segal, E. A Systematic p53 Mutation Library Links Differential Functional Impact to Cancer Mutation Pattern and Evolutionary Conservation. Mol. Cell 2018, 71, 178-190. [CrossRef] [PubMed]

113. Sabapathy, K.; Lane, D.P. Therapeutic targeting of p53: All mutants are equal, but some mutants are more equal than others. Nat. Rev. Clin. Oncol. 2018, 15, 13-30. [CrossRef] [PubMed]

114. Phang, B.H.; Othman, R.; Bougeard, G.; Chia, R.H.; Frebourg, T.; Tang, C.L.; Cheah, P.Y.; Sabapathy, K. Amino-terminal p53 mutations lead to expression of apoptosis proficient p47 and prognosticate better survival, but predispose to tumorigenesis. Proc. Natl. Acad. Sci. USA 2015, 112, 6349-6358. [CrossRef] [PubMed] 
115. Chen, J.; Ruan, H.; Ng, S.M.; Gao, C.; Soo, H.M.; Wu, W.; Zhang, Z.; Wen, Z.; Lane, D.P.; Peng, J. Loss of function of def selectively up-regulates 113 p53 expression to arrest expansion growth of digestive organs in zebrafish. Genes Dev. 2005, 19, 2900-2911. [CrossRef] [PubMed]

116. Donehower, L.A.; Harvey, M.; Slagle, B.L.; McArthur, M.J.; Montgomery, C.A.; Butel, J.S.; Bradley, A. Mice deficient for p53 are developmentally normal but susceptible to spontaneous tumours. Nature 1992, 356, 215-221. [CrossRef]

117. Van Nostrand, J.L.; Bowen, M.E.; Vogel, H.; Barna, M.; Attardi, L.D. The p53 family members have distinct roles during mammalian embryonic development. Cell Death Differ. 2017, 24, 575-579. [CrossRef]

118. Storer, N.Y.; Zon, L.I. Zebrafish models of p53 functions. Cold Spring Harb. Perspect. Biol. 2010, 2 , a001123. [CrossRef]

119. Jain, A.K.; Barton, M.C. p53: Emerging roles in stem cells, development and beyond. Development 2018, 145, dev158360. [CrossRef]

120. Bowen, M.E.; McClendon, J.; Long, H.K.; Sorayya, A.; Van Nostrand, J.L.; Wysocka, J.; Attardi, L.D. The Spatiotemporal Pattern and Intensity of p53 Activation Dictates Phenotypic Diversity in p53-Driven Developmental Syndromes. Dev. Cell 2019, 50, 212-228. [CrossRef]

121. Hinault, C.; Kawamori, D.; Liew, C.W.; Maier, B.; Hu, J.; Keller, S.R.; Mirmira, R.G.; Scrable, H.; Kulkarni, R.N. $\Delta 40$ Isoform of p53 controls $\beta$-cell proliferation and glucose homeostasis in mice. Diabetes 2011, 60, 1210-1222. [CrossRef] [PubMed]

122. Demaria, M.; Ohtani, N.; Youssef, S.A.; Rodier, F.; Toussaint, W.; Mitchell, J.R.; Laberge, R.M.; Vijg, J.; VanSteeg, H.; Dollé, M.E.T.; et al. An essential role for senescent cells in optimal wound healing through secretion of PDGF-AA. Dev. Cell 2014, 31, 722-733. [CrossRef] [PubMed]

123. Turnquist, C.; Horikawa, I.; Foran, E.; Major, E.O.; Vojtesek, B.; Lane, D.P.; Lu, X.; Harris, B.T.; Harris, C.C. p53 isoforms regulate astrocyte-mediated neuroprotection and neurodegeneration. Cell Death Differ. 2016, 23, 1515-1528. [CrossRef] [PubMed]

124. Simón, R.; Aparicio, R.; Housden, B.E.; Bray, S.; Busturia, A. Drosophila p53 controls Notch expression and balances apoptosis and proliferation. Apoptosis 2014, 19, 1430-1443. [CrossRef]

125. Dichtel-Danjoy, M.-L.; Ma, D.; Dourlen, P.; Chatelain, G.; Napoletano, F.; Robin, M.; Corbet, M.; Levet, C.; Hafsi, H.; Hainaut, P.; et al. Drosophila p53 isoforms differentially regulate apoptosis and apoptosis-induced proliferation. Cell Death Differ. 2013, 20, 108-116. [CrossRef]

126. Mehta, S.; Tsai, P.; Lasham, A.; Campbell, H.; Reddel, R.; Braithwaite, A.; Print, C. A study of TP53 RNA splicing illustrates pitfalls of RNA-seq methodology. Cancer Res. 2016, 76, 7151-7159. [CrossRef]

127. Nenutil, R.; Smardova, J.; Pavlova, S.; Hanzelkova, Z.; Muller, P.; Fabian, P.; Hrstka, R.; Janotova, P.; Radina, M.; Lane, D.; et al. Discriminating functional and non-functional p53 in human tumours by p53 and MDM2 immunohistochemistry. J. Pathol. 2005, 207, 251-259. [CrossRef]

128. Ko, C.J.; Myung, P.; Leffell, D.J.; Bourdon, J.C. Cutaneous immunohistochemical staining pattern of p53 isoforms. J. Clin. Pathol. 2018, 71, 1120-1122. [CrossRef]

129. Jiang, W.; Liu, L.; Chen, Y. Simultaneous Detection of Human C-Terminal p53 Isoforms by Single Template Molecularly Imprinted Polymers (MIPs) Coupled with Liquid Chromatography-Tandem Mass Spectrometry (LC-MS/MS)-Based Targeted Proteomics. Anal. Chem. 2018, 90, 3058-3066. [CrossRef]

(C) 2019 by the authors. Licensee MDPI, Basel, Switzerland. This article is an open access article distributed under the terms and conditions of the Creative Commons Attribution (CC BY) license (http://creativecommons.org/licenses/by/4.0/). 